\title{
Contribution of seven legumes residues incorporated into soil and NP fertilizer to maize yield, nitrogen use efficiency and harvest index in degraded soil in the center of Benin
}

\author{
Félix A. KOUELO ${ }^{1 *}$, Pascal HOUNGNANDAN ${ }^{1}$ and Dercon GERD ${ }^{2}$ \\ ${ }^{I}$ Faculty of Agronomy Sciences, University of Abomey-Calavi, Benin. \\ ${ }^{2}$ Soil and Water Management and Crop Nutrition Laboratory, International Atomic Energy Agency, \\ Seibersdorf/IAEA, Benin. \\ *Corresponding author, E-mail: felix.kouelo@fsa.uac.bj
}

\begin{abstract}
A field experiment evaluated the impact of seven legumes cover crops residues incorporated into degraded soil (Aeschynomene histrix, Centrosema pubescens, Chamaecrista rotundifolia, Mucuna pruriens, Pueraria phaseolö̈des, Stylosanthes guianensis and S. Hamata) on maize yield, N uptake and harvest index in the center of Benin. In July 2003, the cover crops were planted and received two level of phosphorus (45 P and 0 P) applied in form of Super Phosphate Triple. In May 2004, two split of nitrogen were added on the residues of the legumes, 30 days after the planting of maize. Minerals fertilizers (N, P) enhanced maize yield, N uptake, harvest index and $\mathrm{N}$ use efficiency. Incorporation of legumes residues improved more maize productivity than minerals fertilizers. The best grain yield (1793.9 kg DM.ha $\left.{ }^{-1}\right)$ and grain $\mathrm{N}$ uptake $\left(149.4 \mathrm{~kg} \mathrm{~N} \mathrm{ha}{ }^{-1}\right)$ were obtained with Mucuna pruriens residues incorporated. The combination of $\mathrm{N}$ and $\mathrm{P}$ to the different residues didn't improve significantly the maize yields. The maize grain yield is explained to $90 \%$ by biomass, harvest index and nitrogen use efficiency. The proportion of explained grain $\mathrm{N}$ uptake in biomass, harvest index and nitrogen use efficiency is $74 \%$. The results demonstrated that growing maize with Mucuna pruriens residue incorporation with NP fertilizers could be more beneficial in the legume-maize cropping system in the study area.
\end{abstract}

(C) 2013 International Formulae Group. All rights reserved.

Keywords: Crop residues, mineral fertilizers, maize yield, NUE, degraded soil.

\section{INTRODUCTION}

By the year 2020, soil degradation could constitute a serious threat endangering the food production and rural livelihoods, especially in the poor and high demography regions in developing countries. The increasing soil degradation seriously threats the agricultural development, due to in declining soil fertility. Low soil fertility, particularly nitrogen $(\mathrm{N})$ and phosphorus $(\mathrm{P})$ deficiencies, is one of the main factors restricting agricultural productivity in subSaharan Africa (Sanchez et al., 1997). Farmers should use more inputs as fertilizer to maintain yields. If not, they should temporarily or permanently give up some farmland.

In south of Benin, on degraded rhodic ferralsols, locally known as "terre de barre", which represents $5 \%$ of total area of the 
country, supports $30 \%$ of the population. This pressure on land leads to fallow period reduction, a fall of soil organic matter content from $2.6 \%$ to $0.8 \%$ and maize grains yield from $1500 \mathrm{~kg} \mathrm{ha}^{-1}$ to less than $400 \mathrm{~kg} \mathrm{ha}^{-1}$ on average, in 23 years. Mineral fertilizers could be part of a solution to correct soil fertility decline and address rising food demands (Fofana et al., 2004). However, average fertilizer used in Africa is only about $8 \mathrm{~kg} \mathrm{ha}^{-1}$ (Henao and Baanante, 1999): prices are high, and the efficiency (including nutrient recoveries and agronomic efficiency) of fertilizers is usually low; their availability in quantity and at proper time has been a matter of serious concern in some developing countries including Benin. A result of this problem is the depletion of soil organic matter on smallholder farms due to continuous cultivation without adequate soil fertility replenishment. To increase the efficiency of mineral fertilizer use, to reduce possible negative side effects (e.g., acidification) and to increase soil organic matter, a more integrated approach has been suggested, combining the judicious use of mineral fertilizers with soil organic amendment such as locally available organic resources, agroforestry system and fallow legumes.

More legumes cover crops were promoted for use as green manure in different regions of the world: Brazil, Honduras, Indonesia, Uganda, Malawi, Nigeria, Mali and Benin. Planted to obtain green manure and organic residues, they cause increased soil organic matter rates, reduce soil erosion, control weed, and nematode incidence and thus improve the physical and chemical properties of soil and minimize soil erosion (Floret and Pontanier, 2001; Houngnandan, 2000).

The Мисипu pruriens species, introduced in 1988, had been quickly adopted by most farmers in southern Benin (Azontondé, 2000). But the rate of adoption fell a few times afterwards because of constraints of management of this cover legume. It covers all the soil preventing farmers from making their usual cultural practices such as ridging. Moreover, it shelters the reptiles.

The aim of the study is to compare the effect of the restitution of seven legumes residues of which Mucuna pruriens on the maize productivity. It will allow farmers to adopt the cover legume of their choice to improve maize yield.

\section{MATERIALS AND METHODS \\ Description of experimental site}

The site of the experiment is situated in Avokanzoun, Djidja township ( $7^{\circ} 20^{\prime} 40^{\prime}$ " North and $1^{\circ} 56^{\prime}$ 00" East), unit of the Research and Development site of the National Institute of Agricultural Research of Benin (Figure 1). The site is characterized by soudano-Guinean climate with two rainy seasons (March to July and September to November). The average annual rainfall, temperature and air relative humidity are respectively $1200 \mathrm{~mm}, 27.2{ }^{\circ} \mathrm{C}$ and $90 \%$ (ASECNA, Bohicon). The experiment is installed on a degraded rhodic ferralsols, "terre de barre" soil classified by USDA as oxisols. It is a degraded sandy soil (sand: 90.42\%, silt: $5.49 \%$ and clay: $4.09 \%$ ). Total soil $\mathrm{C}$ is $0.95 \%$, total soil $\mathrm{N}$ is $0.04 \%$, soil base saturation is 9.52 meq. $100 \mathrm{~g}^{-1}$, soil CEC is 15.25 meq. $100 \mathrm{~g}^{-1}$, available form of soil phosphorus is $38.55 \mathrm{ppm}$ and $\mathrm{pH}$ is 5.79 for 2003.

\section{Experimental set-up}

In 2003, the experiment was conducted using no-till practices on land that had been prepared for seeds multiplication of cover legumes. Seven cover legumes are used with uniform intake of potassium as $\mathrm{KCl}(50 \%)$ at $30 \mathrm{~kg} \cdot \mathrm{ha}^{-1}$. The experimental design was a split-plot arrangement of treatments in a 
randomized complete block design with four replications. The main-plot treatments were $\mathrm{C}$ (control, no cover legumes), $\mathrm{Ah}$ (Aschynomene histrix), $\mathrm{Cp}$ (Centrosema pubescens), Cr (Chamaecrista rotundifolia), Mp (Mucuna pruriens), Pp (Pueraria phaseoloides), Sg (Stylosanthes guianensis) and Sh (Stylosanthes hamata). Main plots were $4 \mathrm{~m}$ wide by $5 \mathrm{~m}$ long. Split-plot treatments were two levels of $\mathrm{P}$ fertilizer: 0 and $45 \mathrm{~kg} \mathrm{P}_{2} \mathrm{O}_{5} \mathrm{ha}^{-1}$, applied at planting. Splitplots were $2.4 \mathrm{~m}$ wide by $4 \mathrm{~m}$ long and accommodated ten rows of cover legumes planted at $75 \mathrm{~cm}$.

In 2004, the experiment was conducted using ridging practices on plots that had been used for cover legumes production. Split-plots were divided into two, the experiment design became split split plot and $\mathrm{P}$ effect became $\mathrm{P}$ back effect. Split split plots treatments were two levels of $\mathrm{N}$ fertilizer: 0 and $60 \mathrm{~kg} \mathrm{~N} \mathrm{ha}^{-1}$, applied 30 days after planting. The site was divided into four replicates $R_{1}, R_{2}, R_{3}$ and $R_{4}$ and space between each replicates being $1 \mathrm{~m}$. Each replicate was divided into thirty-two representing with a space of $80 \mathrm{~cm}$ between each one which was $2.4 \mathrm{~m} \mathrm{x} 4 \mathrm{~m}$ (Table 1).

Initial land preparation was done by hand ridging with a hoe at $15 \mathrm{~cm}$ depth in all plots, incorporating legumes crop residues. Maize variety that is open-pollinated and resistant to maize streak (DMR-SRW, 90 days) was used as a test crop. It was planted at a spacing of $75 \mathrm{~cm} \mathrm{x} 40 \mathrm{~cm}$ with two seeds per hill without singling.

\section{Plant sampling and analyses}

Maize was harvested from square performance within each plot. Thus, the harvested effective area per plot was $5.76 \mathrm{~m}^{2}$ $(3.6 \mathrm{~m} \times 1.6 \mathrm{~m})$. In the harvested area, total fresh weights of maize straw and maize cobs were taken and sub-samples of straw taken. Maize cobs were shelled and weighted and sub-sample taken. These were air-dried and dried in an oven at $75{ }^{\circ} \mathrm{C}$ during 72 hours. These dry weights were recorded.

\section{Parameters calculated}

Yield calculations were done using the following expressions:

$\checkmark \quad$ Dry matter factor $=$ sample dry weight / sample fresh weight;

$\checkmark \quad$ Yield (kg DM ha $\left.{ }^{-1}\right)=$ dry matter factor $\mathrm{x}$ (total fresh weight $\mathrm{x} 10000)$ / Effective area $\left(5.76 \mathrm{~m}^{2}\right)$.

Total nitrogen content in these dry samples is determined by the Kjeldahl method, which is a mineralization in sulfuric acid in the presence of $\mathrm{Se}-\mathrm{K}_{2} \mathrm{SO}_{4}-\mathrm{CuSO}_{4}$ (Bremner and Mulvaney, 1982). Nitrogen yield of straw and grains of maize were calculated through the following expression:

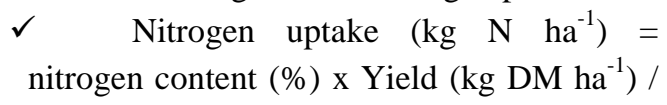
100.

These data were used to calculate:

$\checkmark$ The Harvest Index, HI (Beadle, 1985): HI $=($ Economic yield $\mathrm{x} 100) /$ Biological yield

Where: Economic yield = weight of seeds and Biological yield $=$ above ground biomass.

$\checkmark \quad$ Efficiency of nitrogen use, NUE (Kotchi et al., 2010): NUE = Grains yield / Nitrogen uptake.

\section{Statistical analysis}

Statistical analysis was carried out using SAS 9.2. One way analysis of variance (ANOVA) and Newman-Keuls test were used to determine significant effects of treatments and compare their mean. Pearson's correlation coefficients were used to check for correlation between Harvest Index and Efficiency nitrogen Use. 


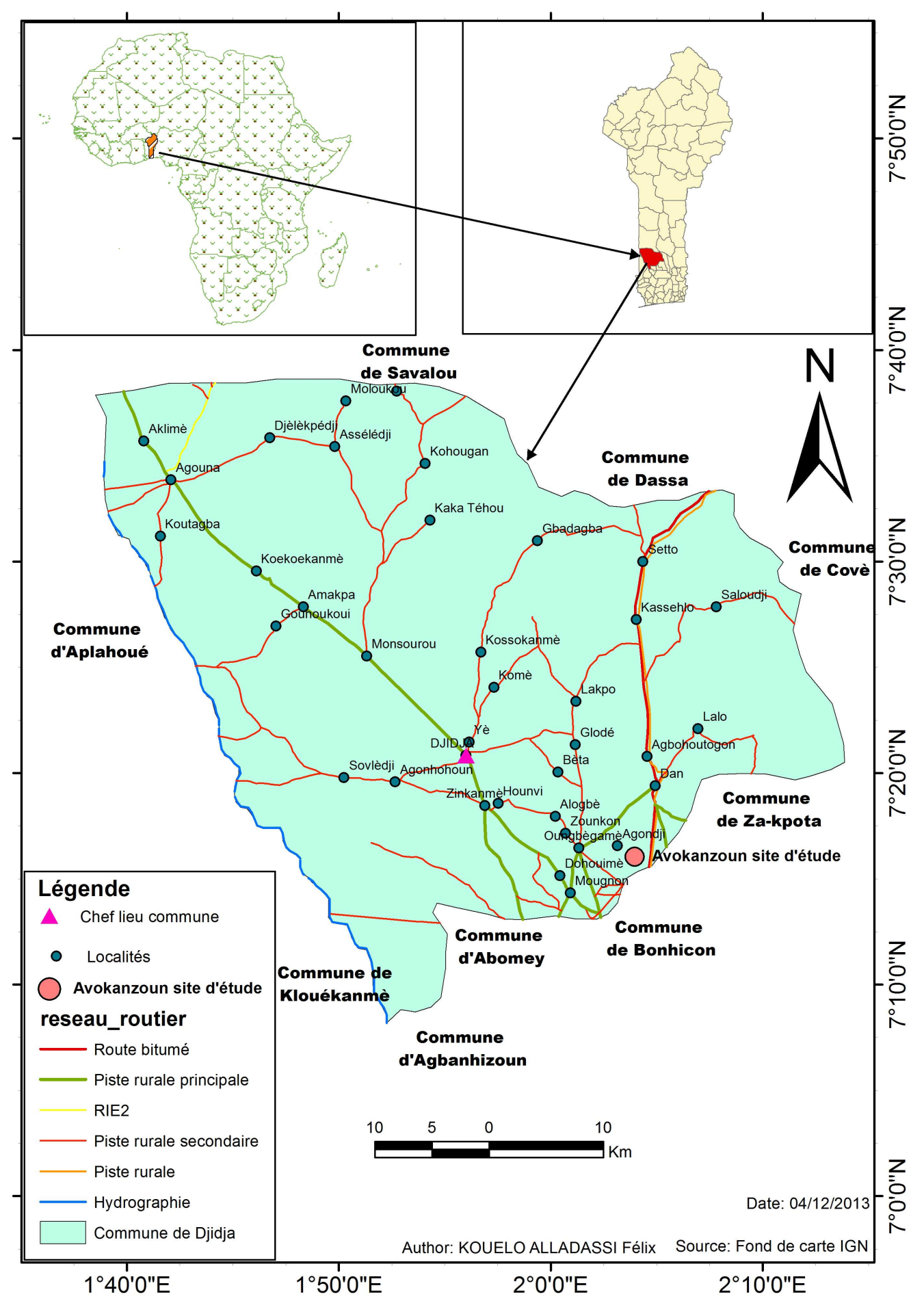

Figure 1: Experimental site. Avokanzoun site d'étude = Study site, Avokanzoun. 
Table 1: The treatments obtained with the combination of the factor study.

\begin{tabular}{|c|c|c|c|c|}
\hline \multirow[t]{2}{*}{ Legume crop residues } & \multicolumn{2}{|c|}{ Phosphorus* } & \multicolumn{2}{|c|}{ Nitrogen } \\
\hline & Without phosphorus (0P) & With 45 kgP.ha $^{-1}$ (45P) & Without nitrogen (0N) & With $60 \mathrm{kgN}^{2} \cdot \mathrm{ha}^{-1}(60 \mathrm{~N})$ \\
\hline Without crop residue $($ Control $=\mathrm{C})$ & $\mathrm{C}+\mathrm{OP}+0 \mathrm{~N}$ & $\mathrm{C}+45 \mathrm{P}+0 \mathrm{~N}$ & $\mathrm{C}+0 \mathrm{P}+60 \mathrm{~N}$ & $\mathrm{C}+45 \mathrm{P}+60 \mathrm{~N}$ \\
\hline Centrosema pubescens (Cp) & $\mathrm{Cp}+\mathrm{OP}+0 \mathrm{~N}$ & $\mathrm{Cp}+45 \mathrm{P}+0 \mathrm{~N}$ & $\mathrm{Cp}+0 \mathrm{P}+60 \mathrm{~N}$ & $\mathrm{Cp}+45 \mathrm{P}+60 \mathrm{~N}$ \\
\hline Chamaecrista rotundifolia $(\mathrm{Cr})$ & $\mathrm{Cr}+\mathrm{OP}+\mathrm{ON}$ & $\mathrm{Cr}+45 \mathrm{P}+0 \mathrm{~N}$ & $\mathrm{Cr}+0 \mathrm{P}+60 \mathrm{~N}$ & $\mathrm{Cr}+45 \mathrm{P}+60 \mathrm{~N}$ \\
\hline Pueraria phaseoloides (Pp) & $\mathrm{Pp}+0 \mathrm{P}+0 \mathrm{~N}$ & $P p+45 P+0 N$ & $\mathrm{Pp}+0 \mathrm{P}+60 \mathrm{~N}$ & $\mathrm{Pp}+45 \mathrm{P}+60 \mathrm{~N}$ \\
\hline Stylosanthes guianensis $(\mathrm{Sg})$ & $\mathrm{Sg}+\mathrm{OP}+\mathrm{ON}$ & $\mathrm{Sg}+45 \mathrm{P}+0 \mathrm{~N}$ & $\mathrm{Sg}+0 \mathrm{P}+60 \mathrm{~N}$ & $\mathrm{Sg}+45 \mathrm{P}+60 \mathrm{~N}$ \\
\hline Stylosanthes hamata (Sh) & $\mathrm{Sh}+0 \mathrm{P}+0 \mathrm{~N}$ & $\mathrm{Sh}+45 \mathrm{P}+0 \mathrm{~N}$ & $\mathrm{Sh}+0 \mathrm{P}+60 \mathrm{~N}$ & $\mathrm{Sh}+45 \mathrm{P}+60 \mathrm{~N}$ \\
\hline
\end{tabular}

$*$ Back effect of phosphorus, $\mathrm{C}=$ Control; $\mathrm{Ah}=$ Aeschynomene histrix $; \mathrm{Cp}=$ Centrosema pubescens; $\mathrm{Cr}=$ Chamaecrista rotundifolia $; \mathrm{Mp}=$ Mucuna pruriens; $\mathrm{Pp}=$ Pueraria phaseoloides; $\mathrm{Sg}=$ Stylosanthes guianensis; $\mathrm{Sh}=$ Stylosanthes hamata $; 0 \mathrm{P}=$ Without Phosphorus; $45 \mathrm{P}=$ Application of $45 \mathrm{kgP}^{-h^{-1}} ; \mathrm{P}=$ Phosphorus; 0N = Without Nitrogen; 60N = Application of $60 \mathrm{kgN}$. ha ${ }^{-1}$; $\mathrm{N}=$ Nitrogen. 


\section{RESULTS}

Maize yields

Legume residues inputs

Maize grain and straw yields responded significantly to cover legume residues inputs (Table 2). The use of cover legumes residues increased the maize grain DM yields from 268 $\mathrm{kg} \mathrm{DM} \mathrm{ha}{ }^{-1}$ (farmers practice) to $567 \mathrm{~kg} \mathrm{DM}$ $\mathrm{ha}^{-1}$ with Stylosanthes hamata residues, and to $1070 \mathrm{~kg} \mathrm{DM} \mathrm{ha}{ }^{-1}$ with Mucuna pruriens residues and the straw DM yields of $1025 \mathrm{~kg}$ $\mathrm{DM} \mathrm{ha}^{-1}$ (Stylosanthes guianensis residues) to $1434 \mathrm{~kg} \mathrm{DM} \mathrm{ha}{ }^{-1}$ (Chamaecrista rotundifolia residues) against $629 \mathrm{~kg} \mathrm{DM} \mathrm{ha}{ }^{-1}$ for the farmers practice (Table 3). All residues then shown a very positive effect on maize grain and straw yield. The highest maize grain yield is obtained with Mucuna pruriens residues followed by those of Chamaecrista rotundifolia, the lowest yield was obtained with Stylosanthes guianensis residues. Maize productivity obtained in the different treatment was used to classify the effect of incorporation of legume residues in ascending order as follows: $\mathrm{C}<\mathrm{Sg}<\mathrm{Mp}<\mathrm{Sh}<\mathrm{Pp}<$ $\mathrm{Cr}<\mathrm{Ah}<\mathrm{Cp}$ for straws and $\mathrm{C}<\mathrm{Cp}<\mathrm{Sg}<$ $\mathrm{Sh}<\mathrm{Ah}<\mathrm{Pp}<\mathrm{Cr}<\mathrm{Mp}$ for grains.

Inorganic fertilizers

The residual effect of the dose of $45 \mathrm{~kg}$ P.ha ${ }^{-1}$ significantly improved the yield of straw and grain maize respectively from $1463.6 \mathrm{~kg} \cdot \mathrm{ha}^{-1}$ to $1849.1 \mathrm{~kg} \cdot \mathrm{ha}^{-1}$ and from $1057.9 \mathrm{~kg} \cdot \mathrm{ha}^{-1}$ to $1602.0 \mathrm{~kg} \cdot \mathrm{ha}^{-1}$. The dose of $60 \mathrm{~kg} \mathrm{~N} \cdot \mathrm{ha}^{-1}$ also significantly improved the yield of maize straw from $1273.1 \mathrm{~kg} \cdot \mathrm{ha}^{-1}$ to $2039.6 \mathrm{~kg} \cdot \mathrm{ha}^{-1}$ and grain yield from 874.3 kg.ha ${ }^{-1}$ to $1785.6 \mathrm{~kg} \cdot \mathrm{ha}^{-1}$.

\section{Interactions between legume residues inputs} and inorganic fertilizers

Cover legume residues combined with $\mathrm{N}$ fertilizer and or residual phosphorus generated increases in maize grain and straw yield. Combined with $\mathrm{N}$ fertilizer and residual phosphorus, cover legume residues generate more maize productivity than their combination with $\mathrm{N}$ fertilizer or residual phosphorus (Figures 2a, 2b, 2c, 2d, 2e and 2f). Centrosema pubescens and Mucuna pruriens combined with $\mathrm{N}$ and $\mathrm{RP}$ produced respectively the highest maize straw yield (2875 kg DM.ha ${ }^{-1}$ ) and maize grains yield (2713 kg DM.ha ${ }^{-1}$ ). But, the analysis of variance indicates no significant difference between treatments combining residue and inorganic fertilizers. This can be explained by the influence of the gradient of soil fertility.

\section{Nitrogen uptake \\ Legume residue inputs}

The $\mathrm{N}$ uptake in straw and grains of maize was respectively $45.1 \mathrm{~kg} \mathrm{~N} \mathrm{ha}^{-1}$ and $32.5 \mathrm{~kg} \mathrm{~N}^{-1}$ in farmers practice. Nitrogen uptake by maize was significantly increased after incorporation of legumes residues (Table 2). Nitrogen uptake in straw and grains of maize increased respectively from $51.9 \mathrm{~kg} \mathrm{~N}$ $\mathrm{ha}^{-1}$ with Stylosanthes guianensis residues to $88.4 \mathrm{~kg} \mathrm{~N}^{-1}$ with Centrosema pubescens residues and from $100.4 \mathrm{~kg} \mathrm{~N} \mathrm{ha}{ }^{-1}$ with Centrosema pubescens residues to $149.4 \mathrm{~kg} \mathrm{~N}$ $\mathrm{ha}^{-1}$ with Mucuna pruriens residues. The $\mathrm{N}$ uptake by maize obtained in the different treatment was used to classify the effect of incorporation of legume residues in ascending order as follows: $\mathrm{C}<\mathrm{Sg}<\mathrm{Pp}<\mathrm{Sh}<\mathrm{Cr}<$ $\mathrm{Mp}<\mathrm{Ah}<\mathrm{Cp}$ for maize straws and $\mathrm{C}<\mathrm{Cp}<$ $\mathrm{Sg}<\mathrm{Pp}<\mathrm{Sh}<\mathrm{Ah}<\mathrm{Cr}<\mathrm{Mp}$ for maize grains.

\section{Inorganic fertilizers}

Inorganic fertilizers impacted significantly the $\mathrm{N}$ uptake by maize. Straw and grains maize $\mathrm{N}$ uptake varied respectively from $55.8 \mathrm{~kg} \mathrm{~N} \mathrm{ha}$ without residual phosphorus to $75.9 \mathrm{~kg} \mathrm{~N}^{-1}$ with residual application of $45 \mathrm{~kg} \mathrm{P} \mathrm{ha}^{-1}$ and from $83.6 \mathrm{~kg} \mathrm{~N}$ $\mathrm{ha}^{-1}$ without residual phosphorus to $127.4 \mathrm{~kg}$ $\mathrm{N} \mathrm{ha}{ }^{-1}$ with residual application of $45 \mathrm{~kg}$ $\mathrm{P} \mathrm{ha}{ }^{-1}$. The contribution of $60 \mathrm{~kg} \mathrm{~N} \cdot \mathrm{ha}^{-1}$ increased the straw $\mathrm{N}$ uptake from $46.5 \mathrm{~kg} \mathrm{~N}$ $\mathrm{ha}^{-1}$ to $85.2 \mathrm{~kg} \mathrm{~N} \mathrm{ha}^{-1}$ and grain $\mathrm{N}$ uptake from $61.9 \mathrm{~kg} \mathrm{~N} \mathrm{ha}^{-1}$ to $149.2 \mathrm{~kg} \mathrm{~N} \mathrm{ha}^{-1}$.

Interactions between legume residue inputs and inorganic fertilizers

Cover legume residues combined with $\mathrm{N}$ fertilizer significantly increased the nitrogen uptake in maize grains and straw. 
The highest $\mathrm{N}$ uptake in maize straw and grains is obtained by applying respectively the combined nitrogen with Centrosema pubescens residues (113 kg N.ha ${ }^{-1}$, Figure 3a) and Mucuna pruriens residues $\left(202 \mathrm{~kg} \mathrm{~N} \cdot \mathrm{ha}^{-1}\right.$, Figure $3 b$ ). Others interactions did not have significant effects. The $\mathrm{N}$ uptake in maize straw is higher when Centrosema pubescens residues are combined with residual phosphorus (115 kg N.ha ${ }^{-1}$, Figure 3c) or residual phosphorus and nitrogen $(152 \mathrm{~kg}$ N.ha ${ }^{-1}$, Figure 3e). However, the highest $\mathrm{N}$ uptake in maize grains is obtained when Mucuna pruriens residues combined with residual phosphorus (177 kg N.ha ${ }^{-1}$, Figure 3d) or residual phosphorus and nitrogen (239 kg N.ha ${ }^{-1}$, Figure 3f).

\section{Harvest index}

\section{Legume residue inputs}

The analysis of variance indicates high significant difference between legume residues incorporated in soil before planting (Table 2). The smallest harvest index of maize obtained in farmer's practice is $31.4 \%$. It increased respectively from $36.3 \%$ with Centrosema pubescens residue to $49.9 \%$ with Mucuna pruriens residues $(\mathrm{C}<\mathrm{Cp}<\mathrm{Ah}<\mathrm{Sh}$ $<\mathrm{Cr}<\mathrm{Sg}<\mathrm{Pp}<\mathrm{Mp}$ ).

\section{Inorganic fertilizers}

The contribution of residual phosphorus (45 $\mathrm{kg} \quad \mathrm{P} \quad \mathrm{ha}^{-1}$ ) significantly increased harvest index of maize from $40.4 \%$ to $43.5 \%$. The application of nitrogen $(60 \mathrm{~kg}$ $\mathrm{N}$ ha $^{-1}$ ) 30 DAP significantly improved harvest index of maize from $39.2 \%$ to $44.6 \%$.

Interactions between legume residue inputs and inorganic fertilizers

The analysis of variance indicates no significant difference between treatments combining legume residues and inorganic fertilizers. However, the arithmetic difference between the treatments enabled us to perceive that Mucuna pruriens residues generated the best harvest index in combination with the residual phosphorus (52\%, Figure 4a), with nitrogen $(50 \%$, Figure $4 \mathrm{~b})$ or both $(52 \%$, Figure 4c).

\section{Nitrogen use efficiency \\ Legume residue inputs}

The incorporation of legume residues in soil improved significantly nitrogen use efficiency in maize from $6.1 \mathrm{~kg}$ Grain $/ \mathrm{kg} \mathrm{N}$ uptake with farmer's practice to $10.0 \mathrm{~kg}$ Grain/kg N uptake with Pueraria phaseoloïdes residues $(\mathrm{C}<\mathrm{Cp}<\mathrm{Sh}<\mathrm{Ah}<\mathrm{Cr}$ $<\mathrm{Mp}<\mathrm{Sg}<\mathrm{Pp}$ ).

\section{Inorganic fertilizers}

Phosphorus doesn't have any significant residual effect on nitrogen use efficiency (Table 2). But, the contribution of nitrogen application $\left(\begin{array}{lllll}60 & \mathrm{~kg} & \mathrm{~N} & \mathrm{ha}^{-1}\end{array}\right)$ significantly increased nitrogen use efficiency from $7.4 \mathrm{~kg}$ Grain $/ \mathrm{kg} \mathrm{N}$ uptake to $8.3 \mathrm{~kg}$ Grain/kg N uptake.

Interactions between legume residue inputs and inorganic fertilizers

The analysis of variance indicates no significant difference between treatments combining legume residues and inorganic fertilizers. Stylosanthes guianensis residues generated the highest maize NUE $(9.2 \mathrm{~kg}$ Grain/kg N uptake) when combined with residual phosphorus (Figure 5a). But, Chamaecrista rotundifolia residues generated the best maize NUE in combination with nitrogen $(9.2 \mathrm{~kg}$ Grain $/ \mathrm{kg} \mathrm{N}$ uptake, Figure $5 b)$ or with residual phosphorus and nitrogen (10.2 kg Grain/kg N uptake, Figure 5c).

\section{Regression}

An examination of correlation coefficients indicates that the straw yield of maize is positively related to grain yield $\left(\mathrm{r}=0.642^{* * *}\right), \mathrm{N}$ uptake in the straw $\left(\mathrm{r}=0.809^{* * * *}\right)$ and in grains $\left(\mathrm{r}=0.661^{* * * *}\right)$. The harvest index and NUE showed no significant relation with yield of maize straw. The grain yield of maize was positively correlated with harvest index $\left(\mathrm{r}=0.763^{* * * *}\right)$, with NUE $\left(\mathrm{r}=0.254^{* *}\right)$, with $\mathrm{N}$ uptake in straw $\left(\mathrm{r}=0.487^{* * * *}\right)$ and in grain $\left(\mathrm{r}=0.973^{* * *}\right)$. The harvest index was positively correlated with $\mathrm{N}$ uptake in grain $\left(\mathrm{r}=0.706^{* * *}\right)$ and with NUE $\left(\mathrm{r}=0.567^{* * *}\right)$. The NUE is negatively 
correlated with the $\mathrm{N}$ uptake in maize straw $\left(\mathrm{r}=-0.398^{* * *}\right)$.

These results indicate that the increase in grain yield is due to increased production of straw. Varieties with high harvest index are the high yielding varieties. Increased NUE led to the decrease of $\mathrm{N}$ uptake in maize straw. These results are similar with those obtained by Bouzerzour et al. (1998).

The multiple regression of grain yield on agronomic traits indicated biomass, harvest index and nitrogen use efficiency account for $90 \%$ of the variation in grain yield:

$\mathrm{RDT}=0.70 \mathrm{BIO}+53.43 \mathrm{HI}-22.88$ NUE - $1895.70\left(\mathrm{r}^{2}=0.9005\right)$.

The multiple regression of grain $\mathrm{N}$ uptake on agronomic traits retains that biomass $\mathrm{N}$ uptake, harvest index and nitrogen use efficiency account for $73 \%$ of the variation in grain $\mathrm{N}$ uptake:

$$
\begin{aligned}
& \mathrm{N}_{\mathrm{RDT}}=0.82 \mathrm{~N}_{\mathrm{BIO}}+4.97 \mathrm{HI}-4.89 \\
& \mathrm{NUE}-118.74\left(\mathrm{r}^{2}=0.7392\right) .
\end{aligned}
$$

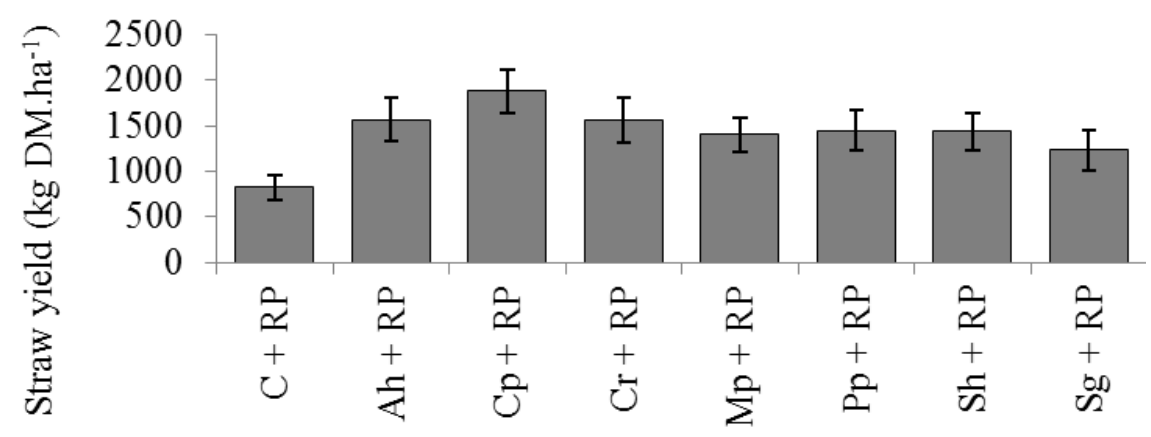

Cover legume residues combined with residual phosphorus

Figure 2a: Effect of cover legume residues combined with residual phosphorus on maize straw yield. $\mathrm{C}=\mathrm{Control} ; \mathrm{Ah}=$ Aeschynomene histrix $; \mathrm{Cp}=$ Centrosema pubescens $; \mathrm{Cr}=$ Chamaecrista rotundifolia $; \mathrm{Mp}=$ Mucuna pruriens; $\mathrm{Pp}=$ Pueraria phaseolö̈des; $\mathrm{Sg}=$ Stylosanthes guianensis; $\mathrm{Sh}=$ Stylosanthes hamata $; \mathrm{RP}=\mathrm{Residual}$ phosphorus; DM = Dry matter.

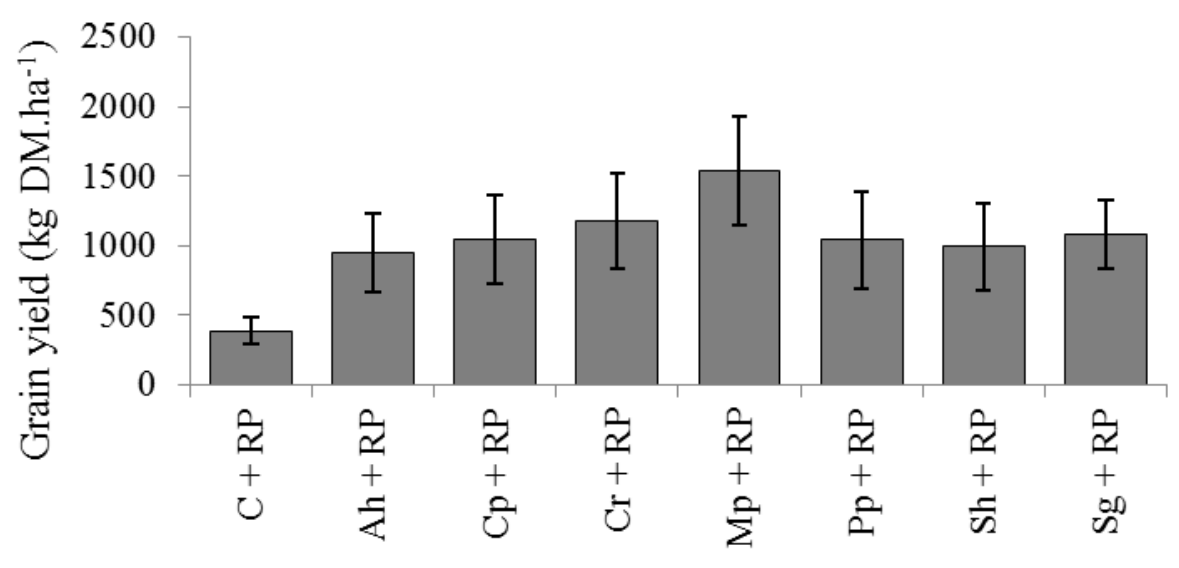

Cover legume residues combined with residual phosphorus

Figure 2b: Effect of cover legume residues combined with residual phosphorus on maize grains yield. $\mathrm{C}=$ Control; $\mathrm{Ah}=$ Aeschynomene histrix $; \mathrm{Cp}=$ Centrosema pubescens; $\mathrm{Cr}=$ Chamaecrista rotundifolia; $\mathrm{Mp}=$ Mucuna pruriens; $\mathrm{Pp}=$ Pueraria phaseolö̈des; $\mathrm{Sg}=$ Stylosanthes guianensis; $\mathrm{Sh}=$ Stylosanthes hamata; $\mathrm{RP}=$ Residual phosphorus; $\mathrm{DM}=$ Dry matter. 


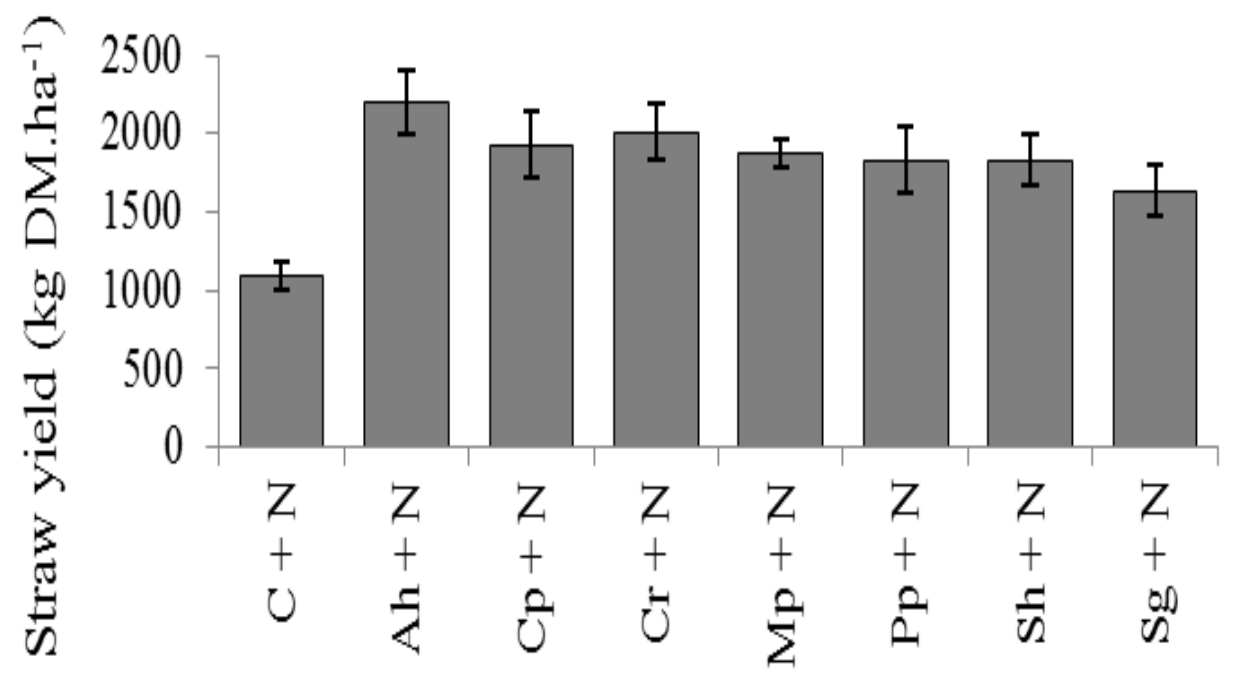

\section{Cover legume residues combined with $\mathrm{N}$ fertilizer}

Figure 2c: Effect of cover legume residues combined with nitrogen on maize straw yield. $\mathrm{C}=\mathrm{Control}$; $\mathrm{Ah}=$ Aeschynomene histrix $; \mathrm{Cp}=$ Centrosema pubescens $; \mathrm{Cr}=$ Chamaecrista rotundifolia $; \mathrm{Mp}=$ Mucuna pruriens; $\mathrm{Pp}=$ Pueraria phaseoloïdes; $\mathrm{Sg}=$ Stylosanthes guianensis; $\mathrm{Sh}=$ Stylosanthes hamata $; \mathrm{N}=$ Nitrogen; $\mathrm{DM}=$ Dry matter.

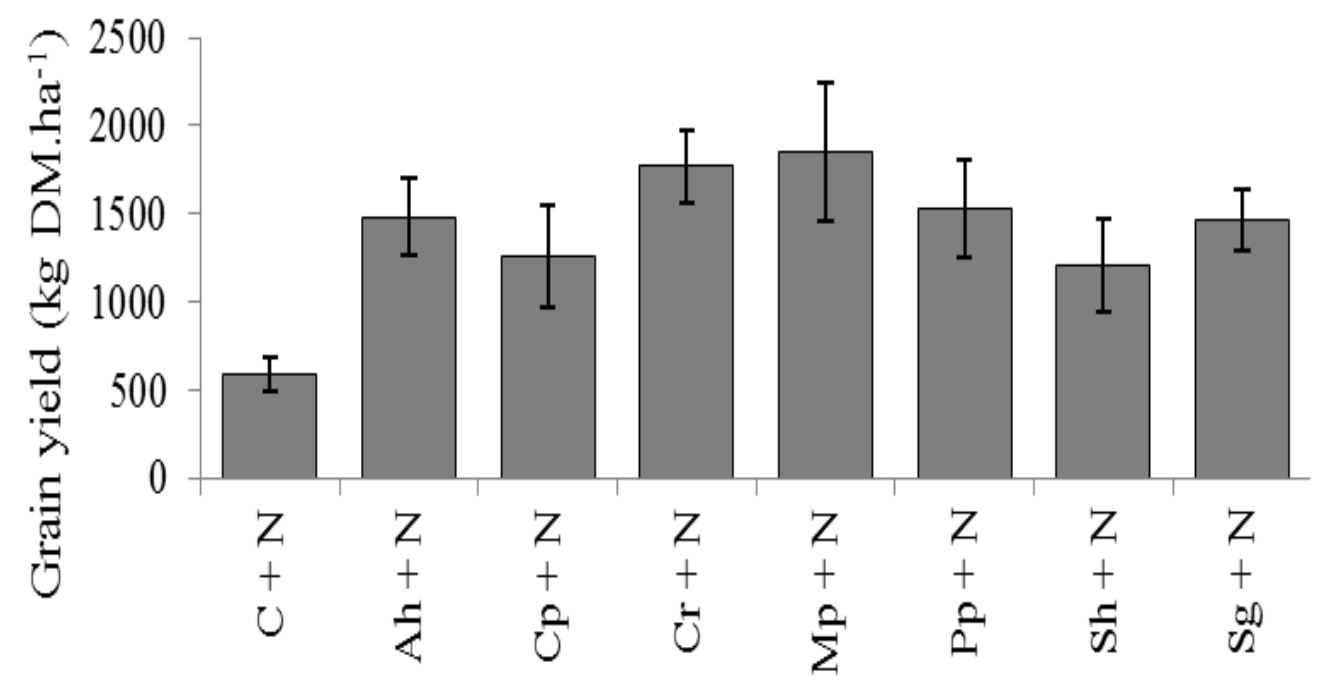

Cover legume residues combined with $\mathrm{N}$ fertilizer

Figure 2d: Effect of cover legume residues combined with nitrogen on maize grains yield. $\mathrm{C}=\mathrm{Control} ; \mathrm{Ah}=$ Aeschynomene histrix $; \mathrm{Cp}=$ Centrosema pubescens $; \mathrm{Cr}=$ Chamaecrista rotundifolia $; \mathrm{Mp}=$ Mucuna pruriens; $\mathrm{Pp}=$ Pueraria phaseolö̈des; $\mathrm{Sg}=$ Stylosanthes guianensis; $\mathrm{Sh}=$ Stylosanthes hamata $; \mathrm{N}=$ Nitrogen; $\mathrm{DM}=\mathrm{Dry}$ matter. 


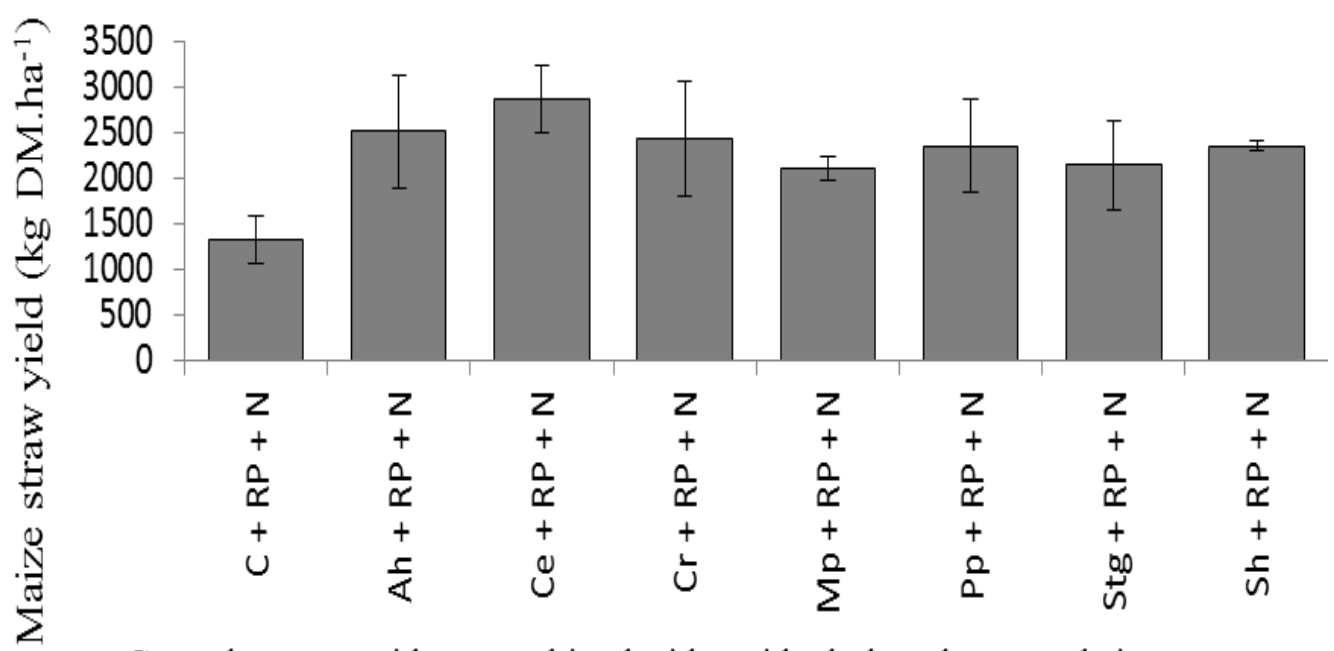

Cover legume residues combined with residual phosphorus and nitrogen

Figure 2e: Effect of cover legume residues combined with residual phosphorus and nitrogen on maize straw yield. $\mathrm{C}=\mathrm{Control} ; \mathrm{Ah}=$ Aeschynomene histrix; $\mathrm{Cp}=$ Centrosema pubescens; $\mathrm{Cr}=$ Chamaecrista rotundifolia $; \mathrm{Mp}=$ Mucuna pruriens; $\mathrm{Pp}=$ Pueraria phaseolö̈des; $\mathrm{Sg}=$ Stylosanthes guianensis; $\mathrm{Sh}=$ Stylosanthes hamata; $\mathrm{RP}=$ Residual phosphorus; $\mathrm{N}=$ Nitrogen; $\mathrm{DM}=$ Dry matter.

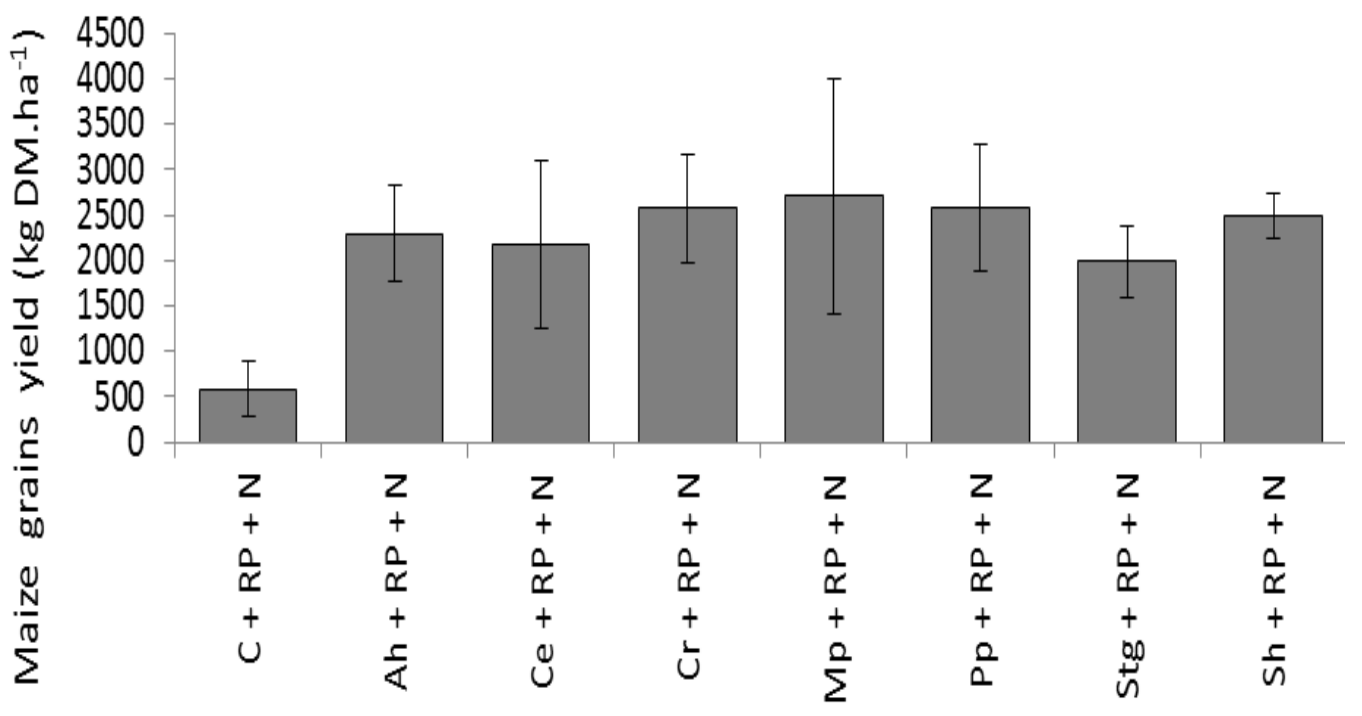

Cover legume residues combined with residual phosphorus and nitrogen

Figure 2f: Effect of cover legume residues combined with residual phosphorus and nitrogen on maize grains yield. $\mathrm{C}=\mathrm{Control} ; \mathrm{Ah}=$ Aeschynomene histrix; $\mathrm{Cp}=$ Centrosema pubescens; $\mathrm{Cr}=$ Chamaecrista rotundifolia $; \mathrm{Mp}=$ Mucuna pruriens; $\mathrm{Pp}=$ Pueraria phaseolö̈des; $\mathrm{Sg}=$ Stylosanthes guianensis; $\mathrm{Sh}=$ Stylosanthes hamata; $\mathrm{RP}=$ Residual phosphorus; $\mathrm{N}=$ Nitrogen; $\mathrm{DM}=$ Dry matter. 


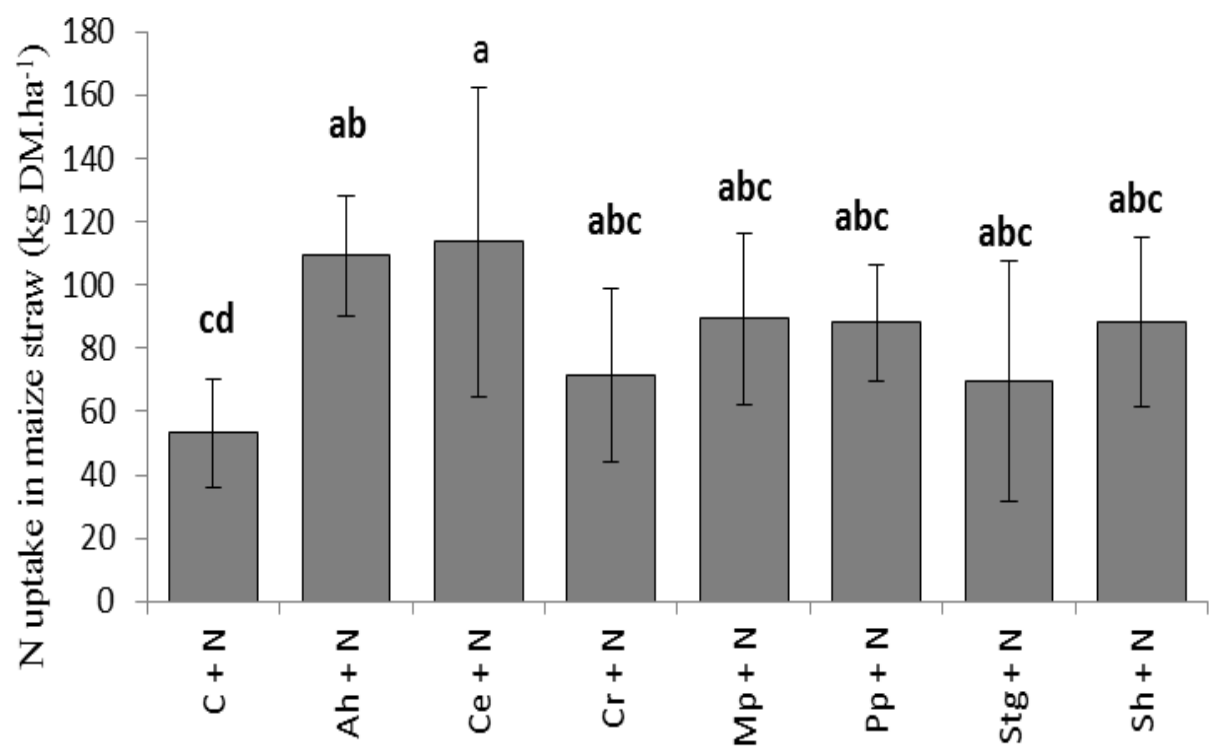

Cover legume residues combined with nitrogen

Figure 3a: Effect of cover legume residues combined with nitrogen on $\mathrm{N}$ uptake in maize straw. $\mathrm{C}=\mathrm{Control} ; \mathrm{Ah}=$ Aeschynomene histrix $; \mathrm{Cp}=$ Centrosema pubescens $; \mathrm{Cr}=$ Chamaecrista rotundifolia $; \mathrm{Mp}=$ Mucuna pruriens; $\mathrm{Pp}=$ Pueraria phaseolö̈des $; \mathrm{Sg}=$ Stylosanthes guianensis; $\mathrm{Sh}=$ Stylosanthes hamata $; \mathrm{N}=\mathrm{Nitrogen} ; \mathrm{DM}=\mathrm{Dry}$ matter.

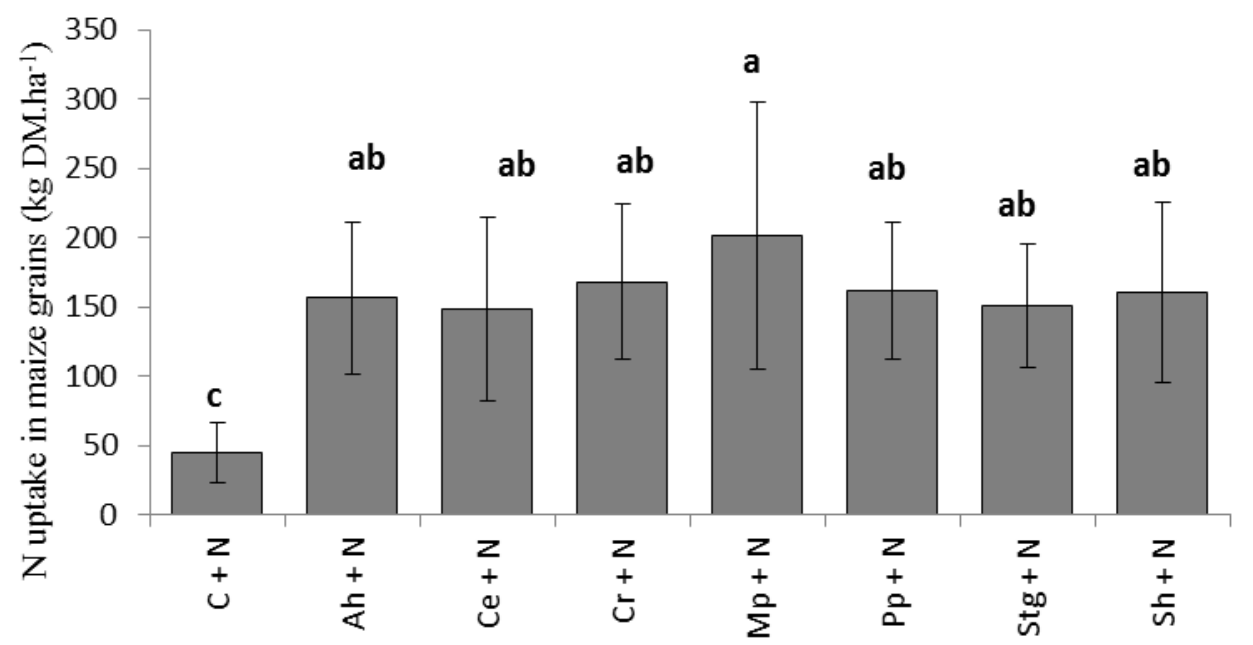

Cover legume residues combined with nitrogen

Figure 3b: Effect of cover legume residues combined with nitrogen on $\mathrm{N}$ uptake in maize grains. $\mathrm{C}=\mathrm{Control} ; \mathrm{Ah}=$ Aeschynomene histrix $; \mathrm{Cp}=$ Centrosema pubescens; $\mathrm{Cr}=$ Chamaecrista rotundifolia $; \mathrm{Mp}=$ Mucuna pruriens; $\mathrm{Pp}=$ Pueraria phaseolö̈des; $\mathrm{Sg}=$ Stylosanthes guianensis; $\mathrm{Sh}=$ Stylosanthes hamata $; \mathrm{N}=$ Nitrogen; $\mathrm{DM}=$ Dry matter. 


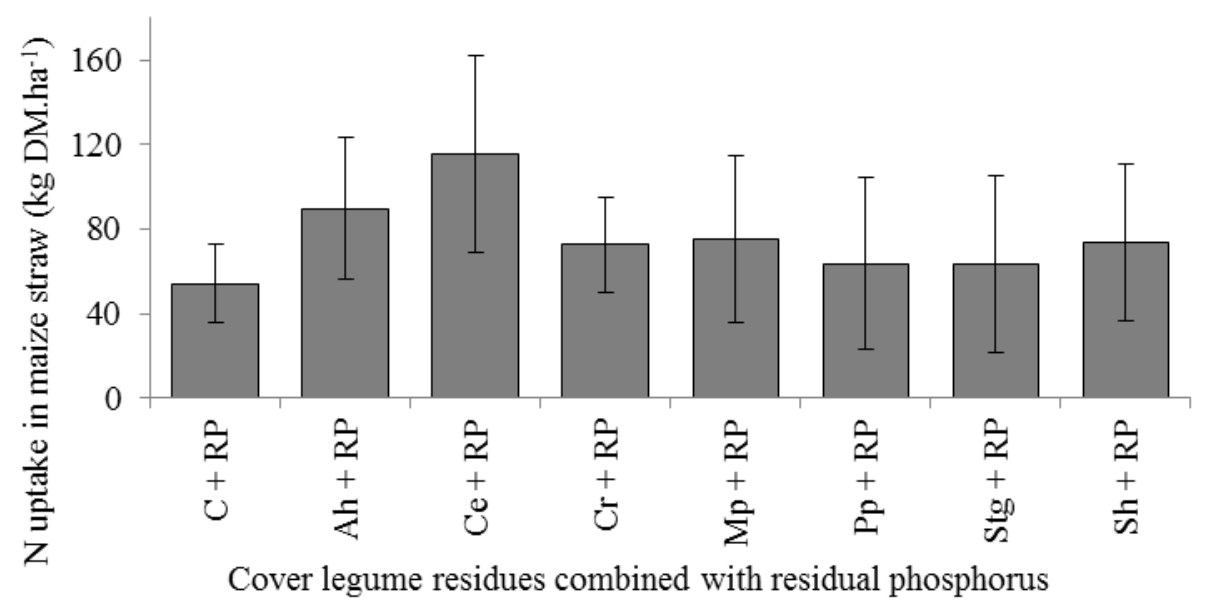

Figure 3c: Effect of cover legume residues combined with residual phosphorus on $\mathrm{N}$ uptake in maize straw. $\mathrm{C}=\mathrm{Control} ; \mathrm{Ah}=$ Aeschynomene histrix $; \mathrm{Cp}=$ Centrosema pubescens $; \mathrm{Cr}=$ Chamaecrista rotundifolia $; \mathrm{Mp}$ $=$ Mucuna pruriens $; \mathrm{Pp}=$ Pueraria phaseoloïdes $; \mathrm{Sg}=$ Stylosanthes guianensis; $\mathrm{Sh}=$ Stylosanthes hamata $; \mathrm{RP}=\mathrm{Residual}$ phosphorus; DM = Dry matter.

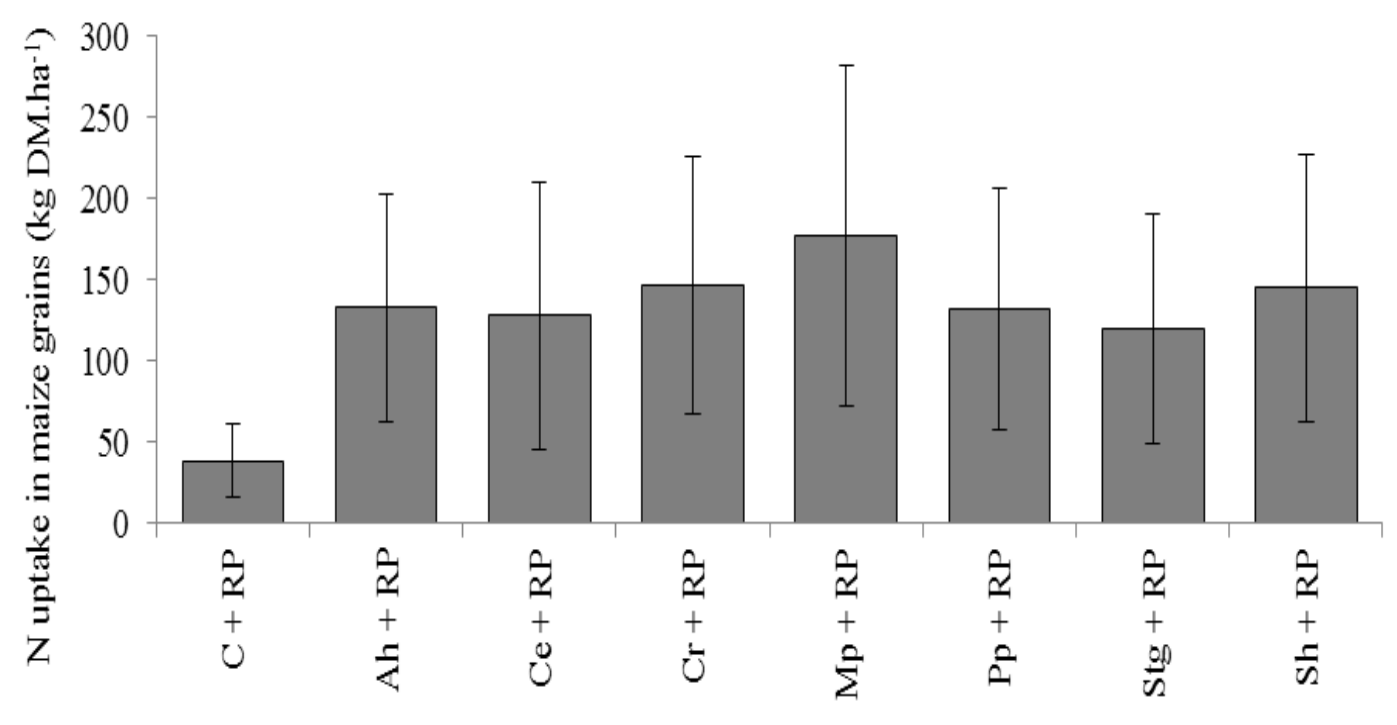

Cover legume residues combined with residual phosphorus

Figure 3d: Effect of cover legume residues combined with residual phosphorus on $\mathrm{N}$ uptake in maize grains. $\mathrm{C}=\mathrm{Control} ; \mathrm{Ah}=$ Aeschynomene histrix $; \mathrm{Cp}=$ Centrosema pubescens $; \mathrm{Cr}=$ Chamaecrista rotundifolia; $\mathrm{Mp}=$ Mucuna pruriens; $\mathrm{Pp}=$ Pueraria phaseolö̈des; $\mathrm{Sg}=$ Stylosanthes guianensis; $\mathrm{Sh}=$ Stylosanthes hamata; $\mathrm{RP}=$ Residual phosphorus; $\mathrm{DM}=$ Dry matter. 


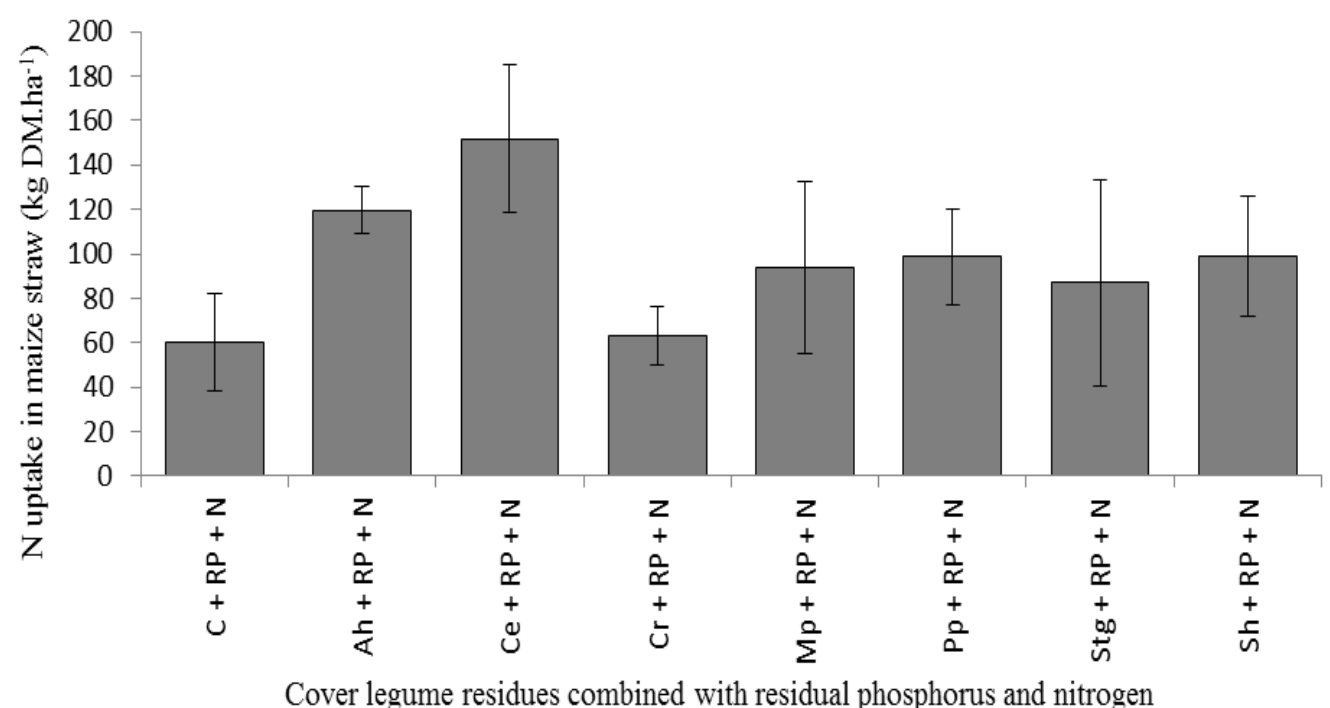

Figure 3e: Effect of cover legume residues combined with residual phosphorus and nitrogen on $\mathrm{N}$ uptake in maize straw. $\mathrm{C}=\mathrm{Control} ; \mathrm{Ah}=$ Aeschynomene histrix $; \mathrm{Cp}=$ Centrosema pubescens; $\mathrm{Cr}=$ Chamaecrista rotundifolia $; \mathrm{Mp}=$ Mucuna pruriens; $\mathrm{Pp}=$ Pueraria phaseolö̈des; $\mathrm{Sg}=$ Stylosanthes guianensis; $\mathrm{Sh}=$ Stylosanthes hamata; $\mathrm{RP}=$ Residual phosphorus; $\mathrm{N}=$ Nitrogen; $\mathrm{DM}=$ Dry matter.

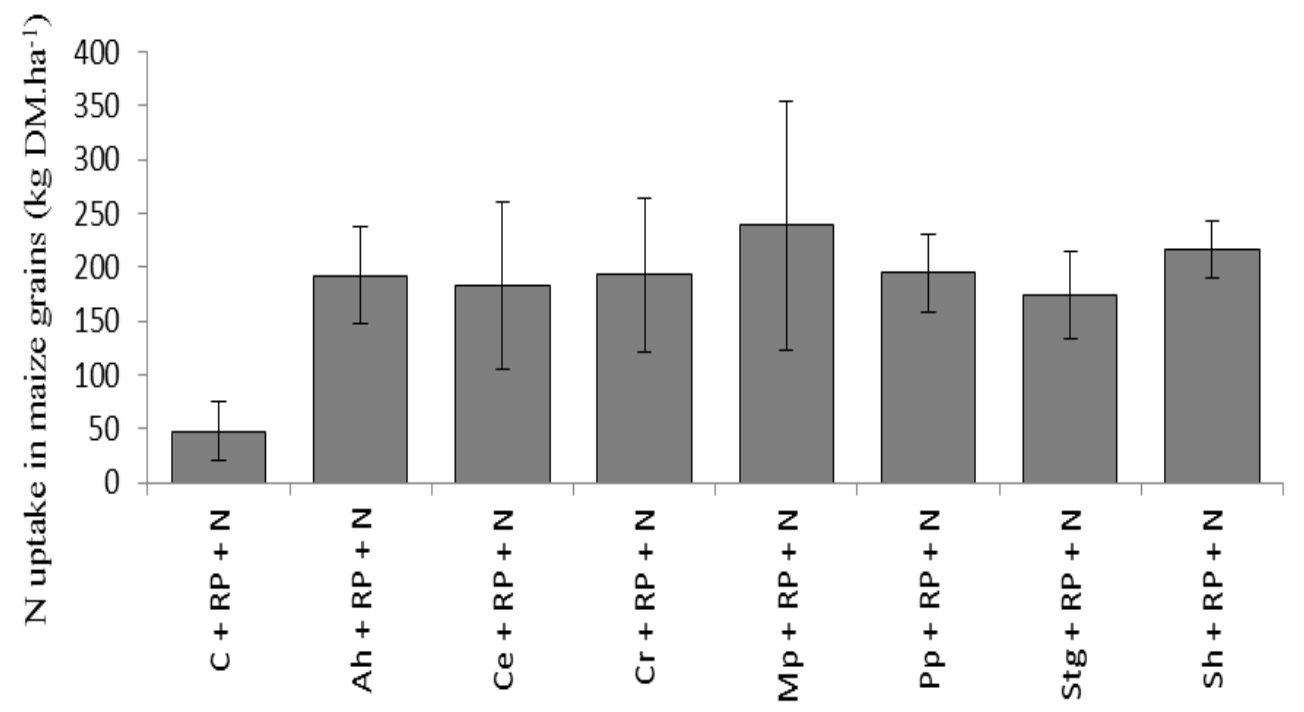

Cover legume residues combined with residual phosphorus and nitrogen

Figure 3f: Effect of cover legume residues combined with residual phosphorus and nitrogen on $\mathrm{N}$ uptake in maize grains. $\mathrm{C}=\mathrm{Control} ; \mathrm{Ah}=$ Aeschynomene histrix; $\mathrm{Cp}=$ Centrosema pubescens; $\mathrm{Cr}=$ Chamaecrista rotundifolia; $\mathrm{Mp}=$ Mucuna pruriens; $\mathrm{Pp}=$ Pueraria phaseolöides; $\mathrm{Sg}=$ Stylosanthes guianensis; $\mathrm{Sh}=$ Stylosanthes hamata; $\mathrm{RP}=$ Residual phosphorus; $\mathrm{N}=$ Nitrogen; $\mathrm{DM}=$ Dry matter. 


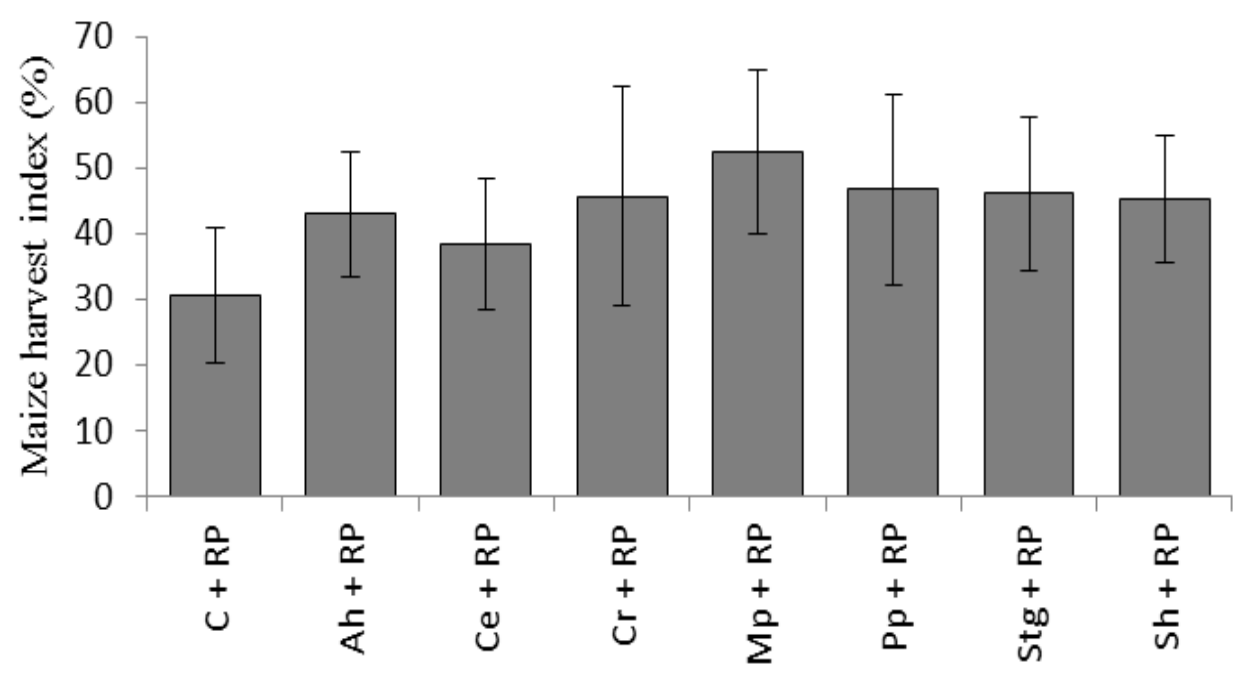

Cover legume residues combined with residual phosphorus

Figure 4a: Effect of cover legume residues combined with residual phosphorus on maize harvest index. $\mathrm{C}=\mathrm{Control} ; \mathrm{Ah}=$ Aeschynomene histrix $; \mathrm{Cp}=$ Centrosema pubescens $; \mathrm{Cr}=$ Chamaecrista rotundifolia ; $\mathrm{Mp}=$ Mucuna pruriens; $\mathrm{Pp}=$ Pueraria phaseoloïdes; $\mathrm{Sg}=$ Stylosanthes guianensis; $\mathrm{Sh}=$ Stylosanthes hamata; $\mathrm{RP}=$ Residual phosphorus.

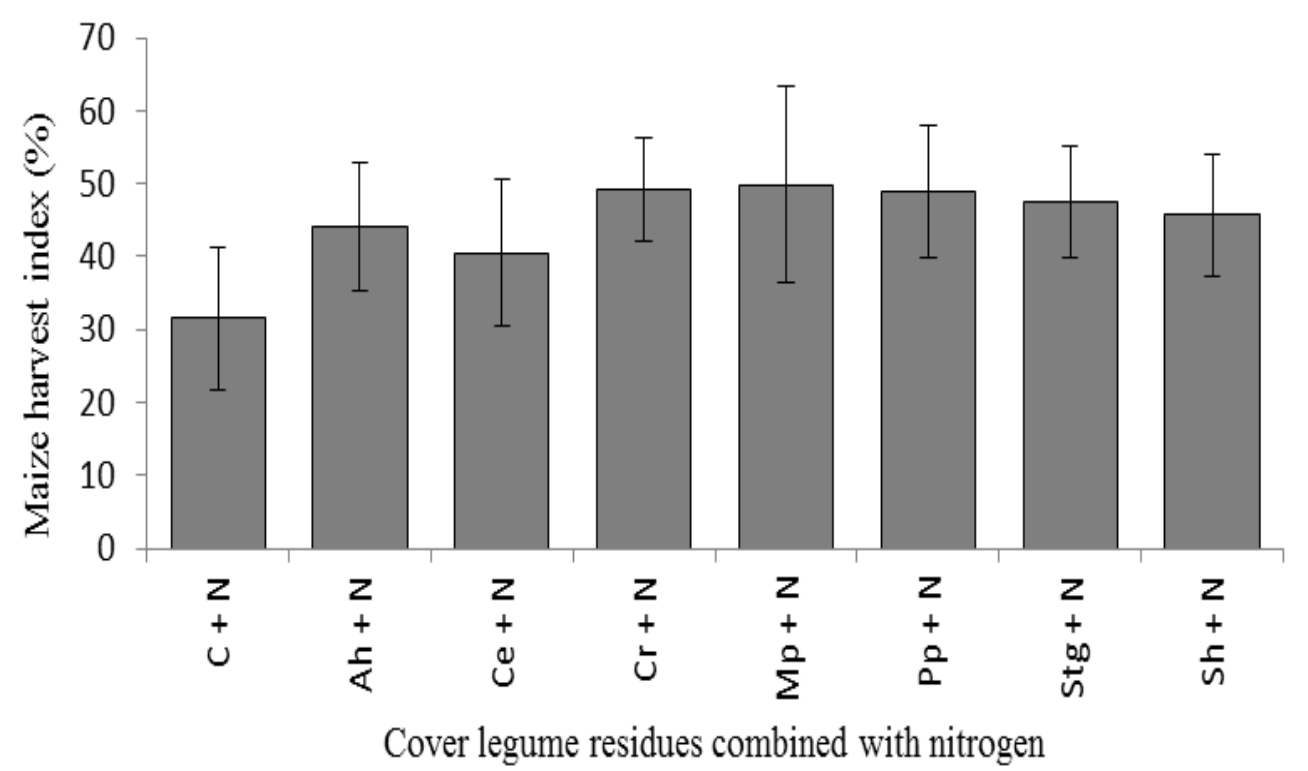

Figure 4b: Effect of cover legume residues combined with nitrogen on maize harvest index. $\mathrm{C}=\mathrm{Control} ; \mathrm{Ah}=$ Aeschynomene histrix $; \mathrm{Cp}=$ Centrosema pubescens; $\mathrm{Cr}=$ Chamaecrista rotundifolia $; \mathrm{Mp}=$ Mucuna pruriens; $\mathrm{Pp}=$ Pueraria phaseoloïdes $; \mathrm{Sg}=$ Stylosanthes guianensis; $\mathrm{Sh}=$ Stylosanthes hamata $; \mathrm{N}=$ Nitrogen. 


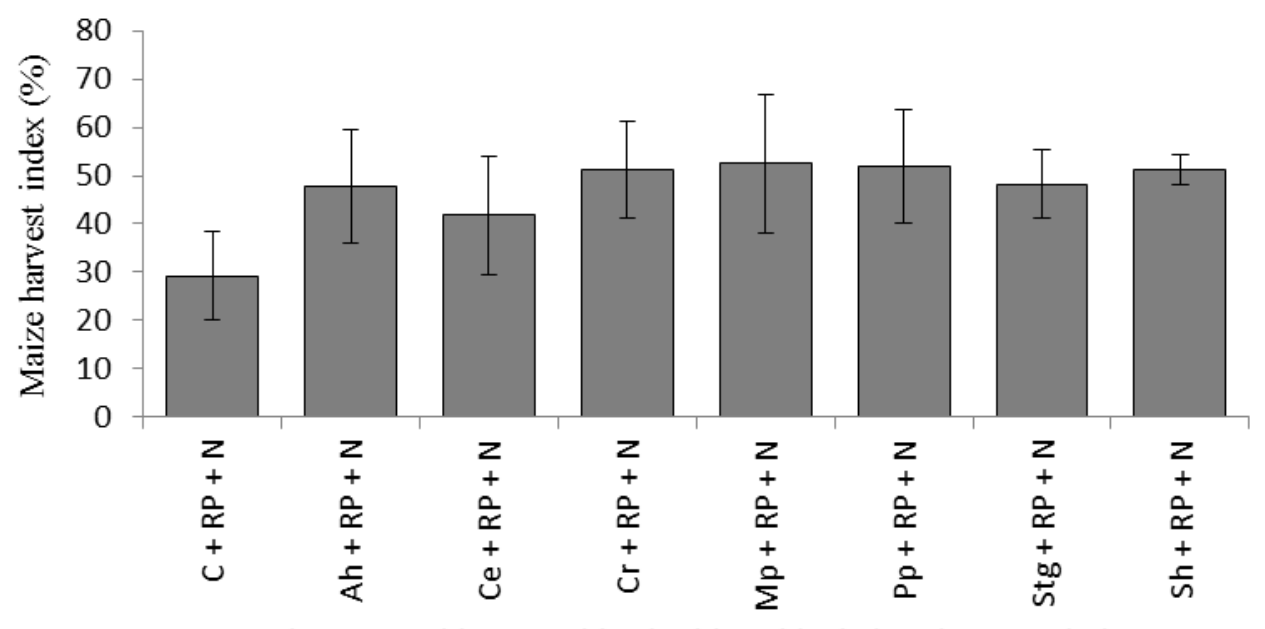

Cover legume residues combined with residual phosphorus and nitrogen

Figure 4c: Effect of cover legume residues combined with residual phosphorus and nitrogen on maize harvest index. $\mathrm{C}=\mathrm{Control} ; \mathrm{Ah}=$ Aeschynomene histrix $; \mathrm{Cp}=$ Centrosema pubescens; $\mathrm{Cr}=$ Chamaecrista rotundifolia $; \mathrm{Mp}=$ Mucuna pruriens; $\mathrm{Pp}=$ Pueraria phaseolö̈des; $\mathrm{Sg}=$ Stylosanthes guianensis; $\mathrm{Sh}=$ Stylosanthes hamata; $\mathrm{RP}=$ Residual phosphorus; $\mathrm{N}=$ Nitrogen.

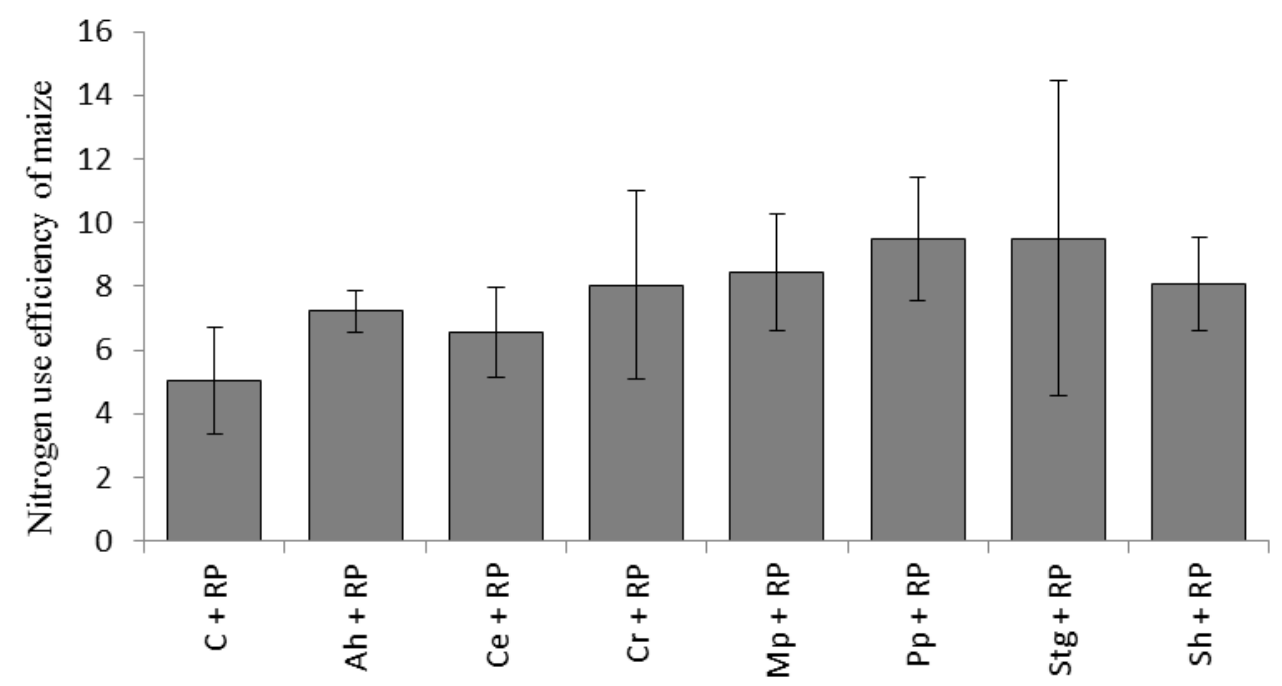

Cover legume residues combined with residual phosphorus

Figure 5a: Effect of cover legume residues combined with residual phosphorus on maize NUE. $\mathrm{C}=\mathrm{Control} ; \mathrm{Ah}=$ Aeschynomene histrix $; \mathrm{Cp}=$ Centrosema pubescens; $\mathrm{Cr}=$ Chamaecrista rotundifolia $; \mathrm{Mp}=$ Mucuna pruriens; $\mathrm{Pp}=$ Pueraria phaseolö̈des; $\mathrm{Sg}=$ Stylosanthes guianensis; $\mathrm{Sh}=$ Stylosanthes hamata $; \mathrm{RP}=\mathrm{Residual} \mathrm{phosphorus;}$ NUE $=$ Nitrogen use efficiency. 


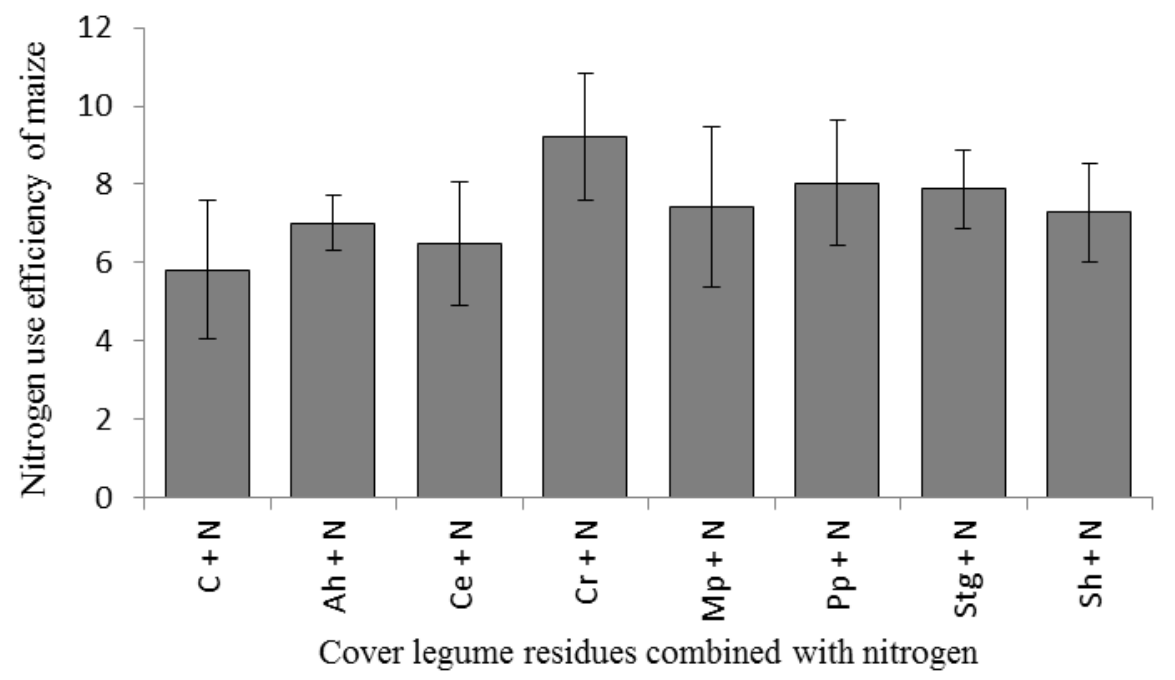

Figure 5b: Effect of cover legume residues combined with nitrogen on maize NUE. C = Control; $\mathrm{Ah}=$ Aeschynomene histrix $; \mathrm{Cp}=$ Centrosema pubescens; $\mathrm{Cr}=$ Chamaecrista rotundifolia $; \mathrm{Mp}=$ Mucuna pruriens; $\mathrm{Pp}=$ Pueraria phaseolö̈des; $\mathrm{Sg}=$ Stylosanthes guianensis; $\mathrm{Sh}=$ Stylosanthes hamata $; \mathrm{N}=$ Nitrogen; NUE = Nitrogen use efficiency.

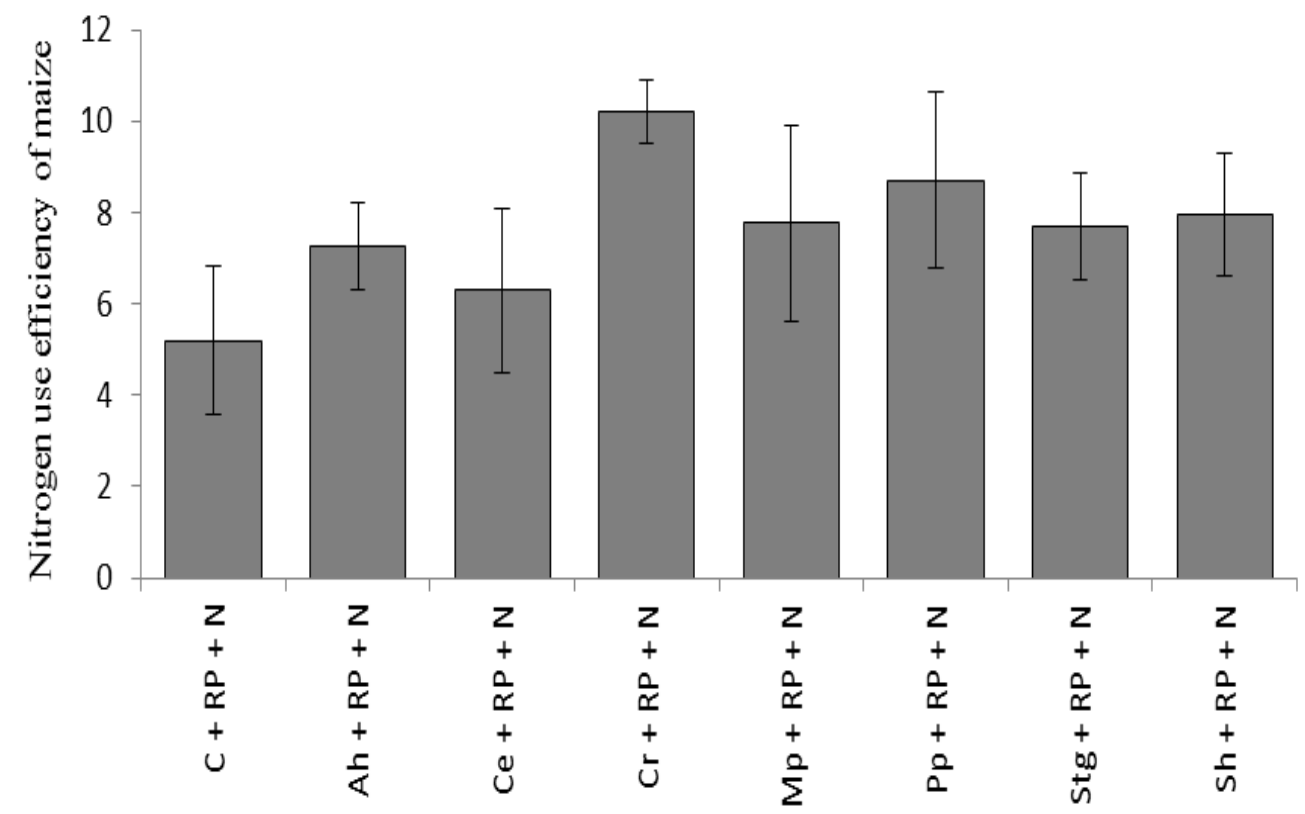

Cover legume residues combined with residual phosphorus and nitrogen

Figure 5c: Effect of cover legume residues combined with residual phosphorus and nitrogen on maize NUE. $\mathrm{C}=\mathrm{Control} ; \mathrm{Ah}=$ Aeschynomene histrix $; \mathrm{Cp}=$ Centrosema pubescens $; \mathrm{Cr}=$ Chamaecrista rotundifolia; $\mathrm{Mp}=$ Mucuna pruriens; $\mathrm{Pp}=$ Pueraria phaseolö̈des; $\mathrm{Sg}=$ Stylosanthes guianensis; $\mathrm{Sh}=$ Stylosanthes hamata; $\mathrm{RP}=$ Residual phosphorus; $\mathrm{N}=$ Nitrogen; NUE = Nitrogen use efficiency. 
Table 2: Summary of analysis of variance (ANOVA) for various parameters studied in the experiment.

\begin{tabular}{|c|c|c|c|c|c|c|c|c|}
\hline $\mathbf{N}^{\mathbf{0}}$ & Parameters studied & Unit & $\begin{array}{l}\text { Legume residues } \\
\text { (LR) Main plots }\end{array}$ & $\begin{array}{l}\text { Residual phosphorus } \\
\text { (RP) Sub plots }\end{array}$ & $\begin{array}{l}\text { Nitrogen }(\mathbf{N}) \\
\text { Sub sub plots }\end{array}$ & $\begin{array}{c}\text { LR x RP } \\
\text { Interactions }\end{array}$ & $\begin{array}{c}\text { LR x N } \\
\text { interactions }\end{array}$ & $\begin{array}{l}\text { LR x RP x N } \\
\text { interactions }\end{array}$ \\
\hline 1 & DM Straw & $\mathrm{Kg} \cdot \mathrm{ha}^{-1}$ & $* * *$ & $* * *$ & $* * *$ & ns & ns & ns \\
\hline 2 & DM Grains & Kg.ha ${ }^{-1}$ & $* * *$ & $* * *$ & $* * *$ & ns & ns & ns \\
\hline 3 & N Straw & Kg.ha ${ }^{-1}$ & $* * *$ & $* * *$ & $* * *$ & ns & $* *$ & ns \\
\hline 4 & N Grains & Kg.ha ${ }^{-1}$ & $* * *$ & $* * *$ & $* * *$ & ns & $*$ & ns \\
\hline 5 & Harvest Index & $\%$ & $* * *$ & $*$ & $* * *$ & ns & ns & ns \\
\hline 6 & Nitrogen Use Efficiency & -- & $* * *$ & ns & $*$ & ns & $*$ & ns \\
\hline
\end{tabular}

$*=$ Stands for significant at $\mathrm{p} \leq 0.05 ; * *=$ Stands for significant at $\mathrm{p} \leq 0.01 ; * * *=$ Stands for significant at $\mathrm{p} \leq 0.001 ; \mathrm{ns}=$ Stands for no significant

$\mathrm{LR}=$ Legume residues; $\mathrm{RP}=$ Residual phosphorus; $\mathrm{N}=$ Nitrogen; $\mathrm{DM}=$ Dry matter; Kg.ha ${ }^{-1}=$ Kilogram per hectare; \% $=$ Percentage. 


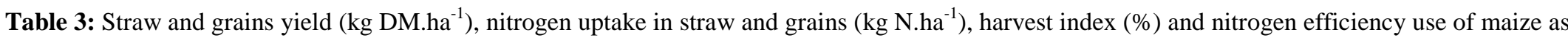
affected by legume residues incorporation, residual phosphorus and nitrogen application.

\begin{tabular}{|c|c|c|c|c|c|c|c|}
\hline Factor & Parameters & DM Straw & DM Grains & N Straw & N Grains & Harvest Index & NUE \\
\hline \multirow{9}{*}{ Legume Residues } & $\mathrm{C}=$ Control & $967.9^{\mathrm{d}}$ & $458.2^{\mathrm{c}}$ & $45.1^{\mathrm{e}}$ & $32.5^{\mathrm{c}}$ & $31.4^{\mathrm{d}}$ & $6.1^{\mathrm{d}}$ \\
\hline & $\mathrm{Ah}=$ Aeschynomene histrix & $1863.3^{\mathrm{ab}}$ & $1374.3^{\mathrm{b}}$ & $76.2^{\mathrm{ab}}$ & $111.2^{\mathrm{b}}$ & $41.4^{\mathrm{bc}}$ & $7.6^{\mathrm{bc}}$ \\
\hline & $\mathrm{Cp}=$ Centrosema pubescens & $2012.7^{\mathrm{a}}$ & $1265.0^{\mathrm{b}}$ & $88.4^{\mathrm{a}}$ & $100.4^{\mathrm{b}}$ & $36.3^{\mathrm{cd}}$ & $6.9^{\mathrm{cd}}$ \\
\hline & $\mathrm{Cr}=$ Chamaecrista rotundifolia & $1861.0^{\mathrm{ab}}$ & $1620.7^{\mathrm{ab}}$ & $67.8^{\mathrm{bc}}$ & $128.7^{\mathrm{ab}}$ & $44.5^{\mathrm{ab}}$ & $8.0^{\mathrm{bc}}$ \\
\hline & $\mathrm{Mp}=$ Mucuna pruriens & $1663.6^{\mathrm{bc}}$ & $1793.9^{\mathrm{a}}$ & $69.7^{\mathrm{bc}}$ & $149.4^{\mathrm{a}}$ & $49.9^{\mathrm{a}}$ & $8.2^{\mathrm{bc}}$ \\
\hline & $\mathrm{Pp}=$ Pueraria phaseoloides & $1689.0^{\mathrm{bc}}$ & $1498.7^{\mathrm{ab}}$ & $60.3^{\mathrm{cd}}$ & $106.4^{\mathrm{b}}$ & $45.4^{\mathrm{ab}}$ & $10.0^{\mathrm{a}}$ \\
\hline & $\mathrm{Sg}=$ Stylosanthes guianensis & $1508.9^{c}$ & $1314.2^{\mathrm{b}}$ & $51.9^{\mathrm{de}}$ & $105.1^{\mathrm{b}}$ & $45.0^{\mathrm{ab}}$ & $8.9^{\mathrm{ab}}$ \\
\hline & Sh $=$ Stylosanthes hamata & $1684.5^{\mathrm{bc}}$ & $1314.6^{\mathrm{b}}$ & $67.5^{\mathrm{bc}}$ & $110.7^{\mathrm{b}}$ & $41.7^{\mathrm{bc}}$ & $7.2^{\mathrm{cd}}$ \\
\hline & LSD & 240.9 & 372.3 & 14.9 & 30.6 & 6.5 & 1.6 \\
\hline \multirow{6}{*}{$\begin{array}{l}\text { Residual } \\
\text { Phosphorus } \\
\left(\mathrm{Kg} \mathrm{P}_{\mathrm{h}} \mathrm{ha}^{-1}\right) \\
\text { Nitrogen }(\mathrm{Kg} \mathrm{N} . \\
\left.\mathrm{ha}^{-1}\right)\end{array}$} & $\mathrm{RP}_{0}=0$ & $1463.6^{b}$ & $1057.9^{b}$ & $55.8^{\mathrm{b}}$ & $83.6^{b}$ & $40.4^{b}$ & 7.9 \\
\hline & $\mathrm{RP}_{1}=45$ & $1849.1^{\mathrm{a}}$ & $1602.0^{\mathrm{a}}$ & $75.9^{\mathrm{a}}$ & $127.4^{\mathrm{a}}$ & $43.5^{\mathrm{a}}$ & 7.8 \\
\hline & LSD & 126.4 & 143.3 & 9.0 & 11.9 & 3.0 & ns \\
\hline & $\mathrm{N}_{0}=0$ & $1273.1^{\mathrm{b}}$ & $874.3^{\mathrm{b}}$ & $46.5^{\mathrm{b}}$ & $61.9^{\mathrm{b}}$ & $39.2^{\mathrm{b}}$ & $8.3^{\mathrm{a}}$ \\
\hline & $\mathrm{N}_{1}=60$ & $2039.6^{\mathrm{a}}$ & $1785.6^{\mathrm{a}}$ & $85.2^{\mathrm{a}}$ & $149.2^{\mathrm{a}}$ & $44.6^{\mathrm{a}}$ & $7.4^{\mathrm{b}}$ \\
\hline & LSD & 129.8 & 144.3 & 7.2 & 12.8 & 2.7 & 0.7 \\
\hline
\end{tabular}

Values marked with the same letters within the same column are not significantly different from each other at $5 \%$ (Student-Newman-Keuls). C = Control; Ah $=$ Aeschynomene histrix; Residual Phosphorus; $\mathrm{RP}_{1}=$ Application of Residual Phosphorus; $\mathrm{N}_{0}=$ Without Nitrogen; $\mathrm{N}_{1}=$ Application nitrogen; $\mathrm{N}=$ Nitrogen; DM = Dry matter; NUE = Nitrogen use efficiency; LSD $=$ Least significant difference. 


\section{DISCUSSION}

Among nutrients, nitrogen is the primary factor in performance. Unfortunately, it is also a nutrient that is the most expensive after phosphorus fertilization and whose management is very sensitive (Sedego et al., 1997). Our results show that nitrogen has a very positive effect on all yield components and confirm those of Yaro et al. (1997). These authors suggest that all parameters of performance increase with increasing doses of minerals fertilizers. They attribute this to strong demand for minerals (especially $\mathrm{N}$ and $\mathrm{P})$.

Legumes can play a major role in improving farm productivity in small holder agriculture as short-term fallow species (Hudgens, 2000). They can increase plant nutrient supply in the soil (especially $\mathrm{N}$ ) and improve soil physical characteristics, thereby improving crop yields (Muller-Samann and Kotschi, 1994). Experiments conducted in western Kenya have demonstrated that higher yields can be obtained when organic residues have been incorporated (Gachengo et al., 1999). Kouyate et al. (2000) also reported an increase in cereal grain and stover yields by 37 and 49\% respectively, when crop residues were incorporated compared with control treatment (no residues incorporation). Shafi et al. (2007) and Bakht et al. (2009) reported an increase in cereal grain yield when crop residues were incorporated, compared with untreated controls (no residues incorporation). Incorporation of residues in soil enhanced the grain yield by 4,51 and $8,93 \%$ when compared with the treatment of residues removal during 2004 and 2005, respectively (Shafi et al., 2010). Mureithi et al. (2003) reported that maize yield with incorporation was $6.1 \mathrm{t} \mathrm{ha}^{-1}$ and in plots where residues had been removed was $5.6 \mathrm{t} \mathrm{ha}^{-1}$. The beneficial effects of residues incorporation of legumes have been reported widely (Shivakumar and Mishra,
2001), attributed to decomposition of their biomass and thereby increased nutrient availability (Pawar and Jadhav, 1995).

Staggenborg et al. (2003) reported that grain $\mathrm{N}$ content increased as applied $\mathrm{N}$ increased. These results were obtained by Shafi et al. (2010) and Acharya and Sharma (1994). Stevenson and Van Kessel (1996) and Shafi et al. (2007) reported that residues incorporation resulted in extra accumulation of $\mathrm{N}$ by maize. Application of $\mathrm{N}$ had increased the $\mathrm{N}$ uptake, which might be attributed to higher $\mathrm{N}$ availability (Parmar and Sharma, 2001) for the crop.

Maize harvest index, the ratio of grain weight to total plant weight, is an important trait associated with the dramatic increases in yield that have occurred in the twentieth century, particularly in the tropical germplasm (Lorenz et al., 2010). The lowest harvest index was recorded in the control treatment as results of Khaliq et al. (2004). Also, our results showed that legumes residues incorporated to soil and $\mathrm{N}, \mathrm{P}$ fertilizers increased significantly harvest index. These results confirm those of Maobe et al. (2010) and Tunku et al. (2010).

Legume residues incorporated in soil improved $\mathrm{N}$ use efficiency of maize. This result was obtained by Wijesinghe et al. (2009) and Sangakkara and Stamp (2009). But, minerals fertilizers $(\mathrm{N}, \mathrm{P})$ application decreased $\mathrm{N}$ use efficiency. This is in accordance with the results obtained by Caldwell and sturratt (1987). Campbell and Davidson (1979) suggested that, inefficient use of $\mathrm{N}$ is associated with increased stress induced by excessive vegetative growth.

\section{Conclusion}

Following this study, we found that legumes residues incorporated in soil or mineral fertilizers application improve significantly the maize yield, $\mathrm{N}$ uptake, 
harvest index and nitrogen use efficiency on degraded soil. By combining legumes residues and mineral fertilizers, the improvement productivity obtained is not being significant. The best grain yield and grain $\mathrm{N}$ uptake were obtained with Mucuna pruriens residues incorporated. When Centrosema pubescens residues are only incorporated, we obtained the highest maize straw yield and straw $\mathrm{N}$ uptake. Mucuna pruriens residues gave the highest harvest index whereas nitrogen use efficiency is higher at Pueraria phaseoloüdes residues. The maize grain yield is explained up to $90 \%$ by biomass, harvest index and nitrogen use efficiency. The proportion of explained grain $\mathrm{N}$ uptake in biomass, harvest index and nitrogen use efficiency is $74 \%$. With rotation legumes-cereals and legumes residues incorporation, degraded soils can be more productive than previously thought.

\section{REFERENCES}

Acharya CL, Sharma PD. 1994. Tillage and mulch effects on soil physical environment, root growth, nutrient uptake and yield of maize and wheat on an Alfisol in north west India. Soil Till. Res., 32: 291-302.

Azontondé A. 2000. Dynamique de la matière organique et de l'azote dans le système Mucuna-maïs sur un sol ferralitique (terre de barre) au sud Bénin. Thèse de doctorat ENSA- Montpellier, France, p. 241.

Bakht J, Shafi M, Jan MT, Shah Z. 2009. Influence of crop residues management, cropping system and $\mathrm{N}$ fertilizer on soil $\mathrm{N}$ and $\mathrm{C}$ dynamics and sustainable wheat production. Soil and Till. Res., 104: 233240.

Beadle CL. 1985. Plant growth analysis. In Techniques in Bio-productivity and photosynthesis, Combs JJ, Hall DO, Long SP, Scurlock JMO (2nd edn). Pergamon Press: Oxford; 20-25.
Bremner JM, Mulvaney CS. 1982. Nitrogen total. In Methods of Soil Analysis, Page AL, Miller RH, Keeney DR (eds). American Society of Agronomy: Madison; 595-624.

Caldwell CD, Stratton CE. 1987. Response of Max spring wheat to management inputs. Canadian J. Plant Sci., 67: 645-652.

Campbell CA, Davidson HR. 1979. Effect of temperature, nitrogen fertilization and moisture stress use by Manitou spring wheat. Canadian J. Plant Sci., 59: 603626.

Floret Ch, Pontanier R. 2001. La jachère en Afrique Tropicale. De la Jachère Naturelle à la Jachère Améliorée. Le Point des Connaissances. John Libbey Erotext : Paris.

Fofana B, Breman H, Carsky RJ, Van Reuler H, Tamelokpo AF, Gnakpenou KD. 2004. Using Mucuna and $\mathrm{P}$ fertilizer to increase maize grain yield and $\mathrm{N}$ ferlitizer use efficiency in the Coastal savanna of Togo. Nutr. Cycling Agroecosyst., 68: 213-222.

Gachengo CN, Palm CA, Jama B, Otieno C. 1999. Tithonia and senna green manures and inorganic fertilizers as phosphorus sources for maize in Western Kenya. Agroforestry Systems., 44: 21-36.

Henao J, Baanante CA. 1999. Estimating Rates of Nutrient Depletion in Soils of Agricultural Lands of Africa. Technical Bulletin T48. IFDC, Muscle Shoals: Alabama, USA, 76 pp.

Houngnandan P. 2000. Efficiency of the use of organic and inorganic nutrients in maize-based cropping systems in Benin. PhD thesis, Ghent University, Belgium, p. 196.

Hudgens RE. 2000. Sustaining soil fertility in Africa: the potential for legume green manures. Soil technologies for sustainable smallholder farming systems in East Africa. Proceedings of the $15^{\text {th }}$ 
Conference of the Soil Science Society of East Africa, Nanyuki, Kenya, pp. 63-78.

Khaliq T, Mahmood T, Kamal J, Masood A. 2004. Effectiveness of farmyard manure, poultry manure and nitrogen for corn (Zea mays L.) productivity. International Journal of Agriculture and Biology, 6(2): 260-263.

Kotchi V, Yao KA, Sitapha D. 2010. Réponse de cinq variétés de riz à l'apport de phosphate naturel de Tilemsi (Mali) sur les sols acides de la région forestière humide de Man (Côte d'Ivoire). Journal of Applied Biosciences, 31: 1895 - 1905.

Kouyate Z, Franzluebbers K, Juo ASR, Hossner L. 2000. Tillage, crop residues, legume rotation, and green manure effects on sorghum and millet yields in the semiarid tropics of Mali. Plant and Soil, 225: 141-151.

Lorenz AJ, Gustafson TJ, Coors JG, De Leon N. 2010. Breeding maize for a bioeconomy: A literature survey examining harvest index and stover yield and their relationship to grain yield. Crop. Sci., 50: 1-12.

Maobe SN, Akundabweni LSM, Mburu MWK, Ndufa JK, Mureithi JG, Gachene CKK, Makini FW, Okello JJ. 2010. Effect of Mucuna green manure and inorganic fertilizer urea nitrogen sources and application rates on harvest index of maize (Zea mays L.). World Journal of Agricultural Sciences, 6 (5): 532-539.

Muller-Samann KM, Kotschi J. 1994. Sustaining Growth: Soil Fertility Management in Tropical Smallholdings. GTZ/CTA, Margraf Verlag: Weikersheim, Germany ; 486.

Mureithi JG, Gachene CKK, Ojiem J. 2003. The role of green manure legumes in smallholder farming systems in Kenya: The Legume Research Network Project.
Tropical and Subtropical Agroecosystems, pp. 57-70.

Parmar DK, Sharma V. 2001. Nitrogen requirement of single hybrid maize ( $\mathrm{Zea}$ mays) -wheat (Triticum aestivum) system under rainfed conditions. Ind. J. Agric. Sci., 71(4): 252-254.

Pawar KP, Jadhav AS. 1995. Nutrient balance in legume sorghum (Sorghum bicolor) cropping sequence. Indian J Agric. Sci., 65(7): 515-518.

Sanchez PA, Shepherd KD, Soule MJ, Place FM, Buresh RJ, Izac AN, Mokwunye AU, Kwesiga FR, Ndiriu CG, Woomer PL. 1997. Soil fertility replenishment in Africa: An investment in natural resource capital. In Replenishing Soil Fertility in Africa, Buresh RJ, Sanchez PA, Calhoun F (eds). Soil Sci Soc Am., 51: 111-149.

Sangakkara UR, Stamp P. 2009. Productivity and nitrogen use of maize as affected by in situ and ex situ green manuring in major and minor seasons of tropical Asia. Acta Agronomica Hungarica, 57(3): 285296.

Sedego PM, Bado BY, Cescas MP, Lompo F, Bationo A. 1997. Effet à long terme des fumures sur les sols et les rendements du maïs au Burkina Faso. Cahiers d'Agriculture., 6: 571-575.

Shafi M, Bakht J, Ullah A, Khan MA. 2010. Effect of crop sequence and crop residues on soil $\mathrm{C}$, soil $\mathrm{N}$ and yield of maize. Pak. J. Bot., 42(3): 1651-1664.

Shafi M, Bakht J, Jan MT, Shah Z. 2007. Soil $\mathrm{C}$ and $\mathrm{N}$ dynamics and maize (Zea mays L.) yield as affected by cropping systems and residues management in Northwestern Pakistan. Soil Till. Res., 94: 520529.

Shivakumar BG, Mishra BN. 2001. Effect of land configuration, nutrient and stover management on growth and yield of 
wheat under limited water supply. Ann Agr Res, 22(4): 462-467.

Staggenborg DA, Whitney DL, Shroyer JP. 2003. Seeding and nitrogen rates required to optimize winter wheat yields following grain sorghum and soybean. Agron. J., 95: 253-259.

Stevenson FC, Van Kessel C. 1996. The nitrogen and non-nitrogen benefits of pea to succeeding crops. Can. J. Plant Sci., 76: 735-745.

Tunku P, Odion EC, Amans EB, Shebayan JAY, Ishaya DB, Adekpe DI. 2010. Yield and economic returns of maize/soyabean mixture as influenced by crop proportion and green manure at Samaru, Nigeria. Agricultura Tropica et Subtropica, 43 (1): 57-63.
Wijesinghe D, Egodawatta C, Attanayake U, Sangakkara UR, Stamp P. 2009. Application method of green manures affect root development of field grown maize and mungbean in tropical minor seasons. International Symposium "Root Research and Applications" RootRAP, 24 September 2009, Boku-Vienna, Austria, p. 2.

Yaro DT, Iwuafor ENO, Chude VO, Tarfa BD. 1997. Use of organic manure and inorganic fertilizer in maize production: A field evaluation. In Strategy for Sustainable Maize Production in West and Central Africa, p. 237-239. 